\title{
An assessment of youth centres in South Africa
}

\author{
Annabel Erulkar \\ Population Council \\ Mags Beksinska \\ Queen Cebekhulu
}

Follow this and additional works at: https://knowledgecommons.popcouncil.org/departments_sbsr-rh

Part of the Demography, Population, and Ecology Commons, International Public Health Commons, Maternal and Child Health Commons, and the Women's Health Commons How does access to this work benefit you? Let us know!

\section{Recommended Citation}

Erulkar, Annabel, Mags Beksinska, and Queen Cebekhulu. 2001. "An assessment of youth centres in South Africa," FRONTIERS Final Report. Nairobi: Population Council. 


\section{An Assessment of Youth Centres in South Africa}

\section{POPULATION COUNCIL}

Annabel S. Erulkar

\section{REPRODUCTIVE HEALTH RESEARCH UNIT}

Mags Beksinska

Queen Cebekhulu

\section{December2001}

This study was funded by the UNITED STATES AGENCY FOR INTERNATIONAL DEVELOPMENT (USAID) under the terms of Cooperative Agreement number HRN-A-00-98-00012-00, Henry J Kaiser Family Foundation and the Department for International Development (DfID). The opinions expressed herein are those of the authors and do not necessarily reflect the views of any of the donors. 


\section{SUMMARY}

Within South Africa there is much interest in expanding youth centre programmes, particularly in the non-governmental sector, in part because of recognition that the HIV/AIDS crisis is disproportionately affecting young South Africans. Donors such as Gates, Kaiser Family Foundation, DfID, and UNFPA are increasingly supporting agencies to develop such centres. This study was designed to give implementing agencies and donors a broad view of how the youth centres function, who they reach, and the quality of information and services. In total, twelve youth centres from three agencies, loveLife, UNFPA-DfID Youth and Adolescent Reproductive Health Programme (YARHP), and KwaZulu-Natal (KZN) Provincial Department of Health, were included in the study. A mini situation analysis of the youth centres was used to assess functioning, quality, and utilization of the facilities. Seven catchment area surveys were conducted among 1,399 young people aged 12 to 24 and their parents.

Overall, 61 percent of youth in the catchment areas are aware of their existence and 29 percent have ever visited the centres. Awareness of loveLife centres is relatively high, which could be due to loveLife centres being physically large structures that tend to be colourful, new, and modern, and often contrasting with their low-income surroundings. The centres that have a wide range of recreational activities tend to attract more repeat visitors than those that focus on clinical services. Repeat visitors were more likely to be male, young, and attending school, and more likely to come to the centres for sports or recreation, compared to the other services offered at the centres. Visitors to the loveLife centres were fairly balanced in terms of gender, whereas the YARHP and KZN DoH centres tended to attract more girls than boys, perhaps because these centres are more focused on RH services. A considerable proportion of visitors to the loveLife and KZN DoH centres were over the official target age, however.

Given that KZN DoH centres focus almost exclusively on clinical services, the vast majority of visitors (97 percent) received clinical services or condoms. Among YARHP sites, a majority of visitors received clinical services or condoms (64 percent), with 22 percent involved in recreational or sports activities and 14 percent receiving life skills. Clients for recreation dominate the loveLife centres, which probably reflects the greater amount of equipment and range of activities available. Vocational training activities do not seem to reach a large number of young people, perhaps because of limits on the number that can be accommodated.

The young people coming for RH services were more likely to be female, out of school, and to be older. Those that took condoms during their visit to the centre were significantly more likely to be out of school and older, with boys more likely to take condoms than girls. The number of clients for RH services seen varies considerably across clinics. A significant proportion of clients are over the official age limit and only eight percent of clients seeing the nurse were male. This is probably due to female services such as hormonal contraceptives requiring regular visits, or to boys seeking services from other sources.

Among young people in the catchment areas of the centres, the most common sources of condoms were public clinics or hospitals (63 percent), followed by youth centres (11 percent), friends ( 9 percent), and private clinics ( 8 percent). Young people getting condoms from public facilities and from youth centres more often take condoms from a dispenser or box than from health personnel. 
Just over half of youth centre visitors who had sex in the last three months and who used condom- last obtained them from the youth centre and 36 percent obtained them from public hospitals or clinics.

This assessment underscored the importance of monitoring performance of programmes and understanding who is being reached with what interventions. Youth centres that focus on providing recreational facilities attract a large number of clients, often boys who are repeat visitors. Providing recreational facilities for young people may go a long way in satisfying programmes' developmental objectives. However, linkages between providing recreation and positive health outcomes are not clear-cut. Centres should not lose sight of their health objectives and should recognize that a significant proportion of young people are in need of quality RH information and services. Therefore, programmes should have ongoing monitoring of the numbers and profiles of young men and women reached with health inputs.

This assessment revealed that youth centres reach about 30 percent of young people in the areas immediately surrounding them and it is likely that coverage is far lower in areas at a greater distance from the centres. With so much of the population in Africa living in rural areas, and with the majority of programmes working within extremely constrained budgets, it is unlikely that youth centres can reach a significant proportion of young people. Finally, the assessment revealed that boys and girls utilize programmes for different reasons. Youth programmes should resist the temptation to homogenize boys and girls into a broad, genderless category "youth." Attention should be paid to the specific needs and circumstances of boys and girls in designing programmes that satisfy their distinct RH needs. 


\section{CONTENTS}

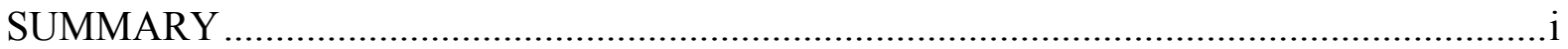

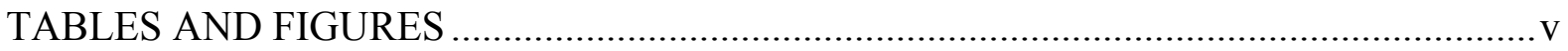

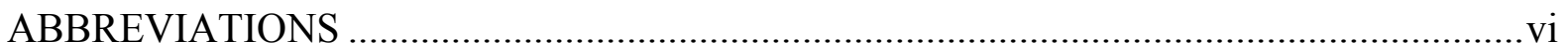

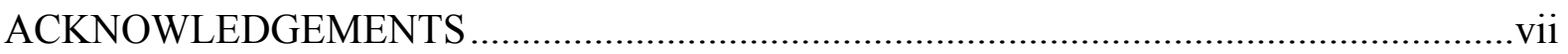

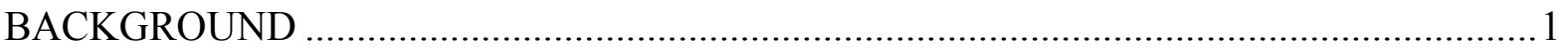

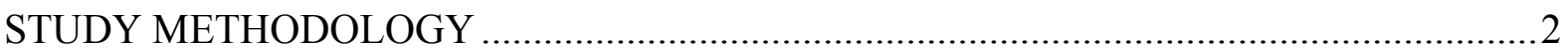

YOUTH CENTRE PROGRAMMES IN SOUTH AFRICA .................................................

loveLife Y-Centres.......................................................... 4

DfID-UNFPA Youth And Adolescent Reproductive Health Programme (YARHP)...4

KwaZulu-Natal Department Of Health Youth Clinics (KZN DOH) $\ldots \ldots \ldots \ldots \ldots \ldots \ldots . .5$

CONTENT OF YOUTH CENTRE PROGRAMMES …..............................................

Life Skills..............................................................6

Reproductive Health Services............................................6

Recreational Services.................................................... 7

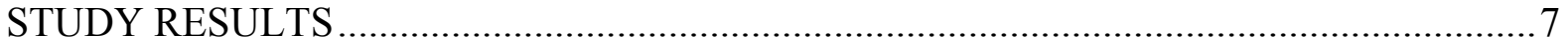

Adolescents' Lifestyles In Catchment Areas.....................................7

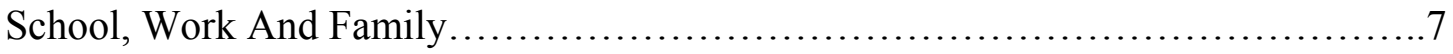

Attitudes Toward Gender Issues............................................

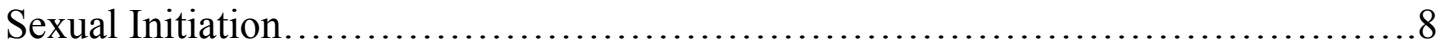

The Nature Of Sexual Relations............................................. 9

Family Planning Use.................................................. 10

Condom Use................................................................

Reproductive Tract Infections.............................................11

Experience With Aids Deaths............................................11

Preferences For Reproductive Health Services............................... 11 
Awareness Of And Exposure To The Centres...................................13

Profile Of Youth Centre Visitors..............................................14

Reasons For Visiting Youth Centres....................................... 15

CLINICAL SERVICES AND CONDOM DISTRIBUTION.............................................. 17

Clinic Client Profile............................................................ 17

Patterns Of Service Utilization................................................ 17

Consultation Time And Duration................................................ 19

Provider Knowledge, Attitudes, And Counselling Skills.........................20

Client Perceptions Of The Provider.........................................22

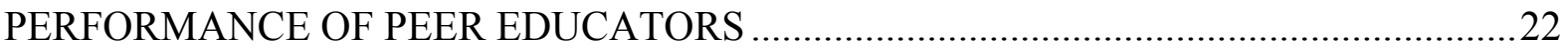

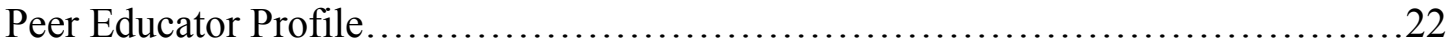

Peer Educator Activities..................................................22

Peer Educator Performance.................................................23

Peer Educator Knowledge, Attitudes, And Interactions With Young People..........24

Clients' Perceptions Of Peer Educators.......................................26

COMPARING YOUTH WHO GO TO CENTRES TO THOSE WHO DO NOT ................27

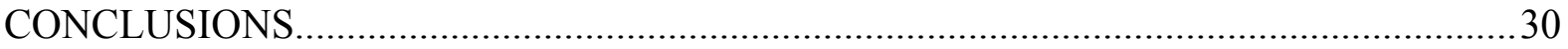

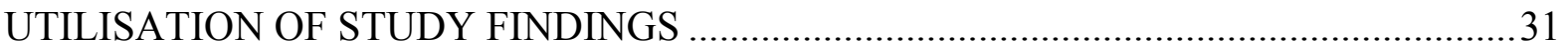

loveLife Programme......................................................... 31

DfID-UNFPA YARHP........................................................ 31

Kwa-Zulu Natal Department Of Health....................................... 32

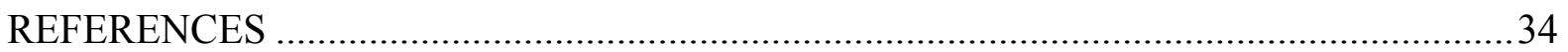

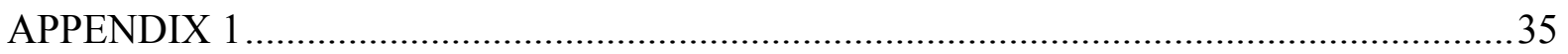

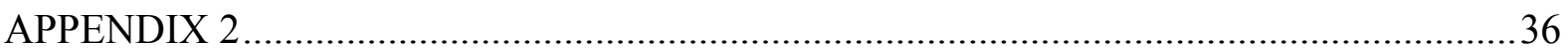




\section{TABLES AND FIGURES}

Table 1: Percentage of respondents who hold gender equitable attitudes, by topic and sex....8

Table 2 Mean scores of the importance of RH service characteristics, by sex...............12

Table 3: Percentage of adolescents who are aware of and have visited youth centres.........13

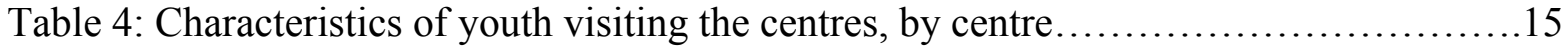

Table 5: Characteristics of clients for clinical services................................ 17

Table 6: Percentage of clinic clients receiving service from the nurse, by agency and sex...18

Table 7: Number and profile of peer educator contacts during one-week period.............23

Table 8: Percentage of peer educators with correct reproductive health knowledge...........24

Table 9: Percentage of peer educators holding "liberal" attitudes to RH information and services for young people...................................................

Table 10: Comparison of RH knowledge between youth who have been to the centres in the last three months and those that have never been to the centres....................27

Figure 1: Cumulative Probability of Having Sex, By Age and Sex.......................

Figure 2: Method Choice Among Adolescents Using Family Planning....................10

Figure 3: Percentage of Youth obtaining Condoms from Dispensers and Clinic Personnel

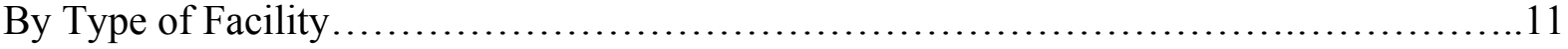

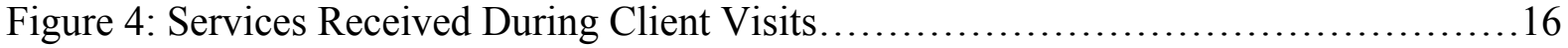

Figure 5: Contraceptive Method Mix, by Implementing Agency $\ldots \ldots \ldots \ldots \ldots \ldots \ldots \ldots \ldots \ldots$

Figure 6: Timing of Clinical Client Visits, by Implementing Agency.....................19

Figure 7: Length of Consultation with the Nurse by Type of Visit.......................20

Figure 8: Cumulative Probability of Boys Initiating Sex, by Youth Centre Exposure........28

Figure 9: Cumulative Probability of Girls Initiating Sex, by Youth Centre Exposure........29 


\section{ABBREVIATIONS}

DfID Department for International Development

DoH Department of Health

DRA Development Research Africa

EC Emergency contraception

FP Family Planning

HIV Human Immuno-Deficiency Virus

IPPF International Planned Parenthood Federation

KZN KwaZulu Natal

$\mathrm{MCH} \quad$ Maternal and Child Health

PE Peer Educator

PPASA Planned Parenthood Association of South Africa

RH Reproductive Health

RTI Reproductive Tract Infection

RHRU Reproductive Health Research Unit

STI Sexually Transmitted Infection

SADHS South Africa Demographic and Health Survey

UNFPA United Nations Fund for Population Activities

VCT Voluntary Counseling and Testing

YARHP Youth and Adolescent Reproductive Health Programme 


\section{ACKNOWLEDGEMENTS}

We would like to acknowledge the following individuals and organizations for their assistance and support in this study. The Planned Parenthood Association of South Africa (PPASA), Department of Health KwaZulu Natal, Department of Health Northern Province, Department of Health North West Province, Department of Health Free State and loveLife, all recognized the importance of study early on, and were kind enough to open their doors to our study teams. We thank them for the support and co-operation they gave study staff during data collection. From these organizations we thank, in particular, Julitta Duncan, David Harrison, Thembi Mazibuko, Hilda Marhinga, Sipho Dayel, Ester Synman, Nomalizo Milsana, Chris Mtubatuba and Mamotho Khotseng. Special thanks to D.R.A. development for conducting the community survey component of the study and assisting in data capturing.

We are grateful to USAID, the loveLife programme funded by Henry J Kaiser Family Foundation (US), and Department for International Development (DfID) for financial assistance to the study.

We thank Ndugga Maggwa and Ian Askew of the Population Council for their guidance, technical support, and comments on draft reports. Lucy Ng'ang'a and Gillian Mackay, also of the Population Council, provided invaluable support from the standpoint of data and logistics. Terri Collins and Ben McGary also gave significant support and input into the study.

Finally, we would like to thank staff in all the youth centres who opened their doors to us and were so giving of their time, as well as all the young people who participated in this research. 


\section{BACKGROUND}

Increasing attention is being focused on the reproductive health needs of young people in South Africa where HIV/AIDS is of increasing concern and rates of sexual violence are among the highest in the world. Like other countries in Africa, South Africa is grappling with how to reach young people with reproductive health messages and how to increase their access to RH services such as family planning services, condoms, STI services, abortion and post abortion care services, and voluntary counselling and testing (VCT). Alarming HIV rates are emerging, with an estimated 16 percent of young people aged 15 to $19 \mathrm{HIV}+$ (National Department of Health, 2000). Public health officials in South Africa feel an urgent need to implement RH programmes and donors are paying considerable attention to the needs of South Africa.

There are a number of national-level activities being implemented in South Africa that target youth and adolescents, spanning training activities, accreditation of clinical services, and policy. Centre for Development and Population Activities (CEDPA) is working with Young Men's Christian Association (YMCA) in training of trainers for peer education. Marie Stopes has been training health care professionals in adolescent friendly health services. The loveLife programme has been implementing a nationwide media, service delivery and advocacy project, with media outlets including TV, radio and print media. National Adolescent Friendly Clinic Initiative (NAFCI) has developed a set of standards of quality for adolescent friendly health services. Using specially developed criteria, public sector clinics are undergoing a process of accreditation for youth friendly services. Guidelines on Youth and Adolescent Health policy have been drafted by the Department of Health.

South Africa has a fairly extensive network of youth centres throughout the country that are being implemented by a variety of agencies. Currently, the main implementers of youth centres are the Planned Parenthood Association of South Africa (PPASA), the loveLife programme, and the Youth and Adolescent Reproductive Health Programme (YARHP), which has contracted PPASA to establish youth centres on behalf of three Provincial Departments of Health. In addition, the KwaZulu-Natal Department of Health (KZN DoH) has historically run a number of youth centres in KwaZulu-Natal Province. Currently, most programmes in sub-Saharan Africa aim to reach both boys and girls, in- and out-of-school, and target a defined age range. The content and configuration of youth centre programmes are highly variable, differing according to organizational goals, objectives of the programme, financial and human resources, as well as political and cultural considerations. Similarly, the youth centres assessed in this study - those under the loveLife programme, Department of Health centres, and Youth and Adolescent Reproductive Health centres - represent a wide range of models.

At the same time, information to guide programme planners on the quality, functioning, and impact of existing programmes for young people - in South Africa and in sub-Saharan Africa generally - is limited. While there have been a number of assessments of RH youth programmes, the majority have been narrow and not rigorous. Relatively few studies have utilized systematically collected data - both qualitative and quantitative - from a variety of sources. In addition, given the sensitive nature of RH services for unmarried youth, few studies have paid adequate attention to perceptions and acceptance of such services, as well as barriers that young people face in seeking those services.

Within South Africa there is much interest in expanding existing youth centre programmes, particularly in the non-governmental sector. Donors such as Gates, Kaiser Family Foundation, DfID, and UNFPA are increasingly supporting agencies to develop centres for young people. However, assessments of youth centres in other countries have shown mixed 
results from this approach. A study in Mexico demonstrated that youth centres reach relatively small numbers of youth and are often not cost effective (Townsend et. al., 1987). Another programme in Mexico, Gente Joven, found that the centres were reaching small numbers of youth - mostly youth who were already highly motivated and knowledgeable about RH issues (Marques, 1993). Recent assessments of youth centres run by family planning organizations in Kenya, Zimbabwe and Ghana revealed that staff are highly knowledgeable on RH matters, particularly HIV/AIDS. At the same time, most centres were dominated by older boys and were less successful in attracting girls (Erulkar and Mensch, 1997, Glover, et. al., 1998, Phiri and Erulkar, 1997).

Given the interest in expanding the youth centre approach, agencies in South Africa are interested in examining the effectiveness of centres in reaching adolescents with information, life skills and services. Further, the range of different youth centre models being implemented in the country permits greater understanding of how different combinations of services perform, in terms of what services are provided, how they are provided, and to whom. The study was designed to give implementing agencies and donors a broad view of how the youth centres function, who they reach, and the quality of information and services.

All programmes have stated objectives that are health-related, such as decreasing HIV prevalence or improving the health status of young people. Therefore, the study focussed on examining outputs directly associated with health outcomes: health information, life skills, counselling, and health services. In addition, the loveLife programme considers itself to have a wider set of objectives that focus on developmental processes, which this study did not address.

In total, twelve youth centres were included in the study, four from loveLife, two from the KwaZulu Natal Provincial Department of Health, and six from the DfID-UNFPA Youth and Adolescent Reproductive Health Programme. Of the twelve centres visited, seven had fully operational peer education programmes, including two loveLife centres, one KZN DoH centre, and four YARHP centres.

\section{STUDY METHODOLOGY}

The ultimate objective of this study was to inform policymakers, programme managers and donors of the quality, functioning, utilization, and effectiveness of alternative youth centre approaches in South Africa. Specifically, the study aimed to:

- Measure the performance of different youth centre models in terms of their functioning, the quality of services provided, and the number, proportion and type of adolescents reached with information and services.

- Assess the performance of peer educators attached to youth centre programmes in terms of the number and profiles of adolescents reached, and the perceptions of young people of this cadre of staff.

- Understand community and youth awareness and perceptions of youth centres as well as the extent to which they are reaching youth in the catchment areas.

- Assess the cost per youth reached through the centres with different types of services, including information, life skills, and RH services.

The study collected information from a variety of sources in order to yield a broad picture of youth centre and peer educator functioning, quality, coverage and effect (Appendix 1). The mini situation analysis of the youth centres was used to assess functioning, quality, and utilization of the facilities. Catchment area surveys were conducted among young people 
aged 12 to 24 and a sample of their parents in the catchment areas of seven of the twelve centres. At least one centre from each of the three programmes was selected for the catchment area survey, as well as centres spanning the range of youth centre models in the study. Catchment area surveys explored awareness and perceptions of the centres and the peer educators, as well as patterns of utilization and reasons for non-use. The proportion of adolescents living in the catchment areas who use the youth centres, and/or whose knowledge, attitudes and behaviour are influenced by their interaction with the centres, are critical indicators of the impact of these programmes.

Data were compiled into spreadsheets especially designed to capture fixed and variable costs incurred in each of the programmes including occupancy, equipment, commodities, personnel and peer educator training. Data were drawn from financial and administrative records with the assistance of project managers. These data were analysed to determine the cost per user for each programme. The results of the cost analysis are reported separately.

Four teams of five interviewers each collected data in the twelve youth centres during October 2000. The teams spent five to seven days at each youth centre, depending on how many days the youth centre was operational during the week of data collection. Reproductive Health Research Unit (RHRU) staff supervised data collection in each of the sites and also conducted a limited amount of interviewing. For the catchment area surveys, an independent research company, Development Research Africa (DRA) was contracted to conduct the data collection, data entry and cleaning. 


\section{Youth Centre Programmes In South Africa}

Each of the twelve youth centres studied is different, however the greatest differences are seen along organizational lines. Table 2 outlines the main characteristics of the centres studied. loveLife centres are large, stand-alone facilities targeted for adolescents only, offering a wide range of recreational and vocational activities, as well as life skills and RH services. The centres associated with YARHP make use of existing government facilities. Some are stand-alone and some are integrated centres. Their recreational and vocational activities are considerably more limited than loveLife centres. KwaZulu-Natal Department of Health Youth clinics offer only RH counselling and services in stand-alone clinics for adolescents.

\section{loveLife Y-Centres}

The loveLife Programme in South Africa is a national programme that "aims to reduce the incidence of HIV among $15-20$ year olds by 50 percent over the next three to five years" (loveLife, 2000). loveLife targets adolescent boys and girls aged 12 to 17, and is a collaboration between the Department of Health, the National Youth Commission, and UNICEF. Organizations that are taking the lead in implementing loveLife activities are PPASA, Advocacy Initiatives, Media Training Centre, and Health Systems Trust.

Reproductive Health Research Unit (RHRU) is the lead research organization. Youth centres, or "Y-Centres," as they are called under loveLife are just one component of the programme, which also includes large-scale media and entertainment initiatives, print and radio, a telephone help line, and research.

Y-Centres are large multi-purpose youth centres combining indoor and outdoor recreation and sports facilities, computer training, community radio, sexual health education, life skills, counselling, and clinical services. At their inception, Y-Centres were considered the central mechanism for information and service delivery under loveLife. According to loveLife: "The primary purpose of the Y-Centres is to demonstrate the effectiveness of a non-clinical environment in providing sexual health education and care for adolescents" (loveLife, 2000). Located in urban centres or peri-urban sites, Y-Centres are large, well-equipped, stand-alone facilities, with a wide array of activities available to adolescents who go there. Y-Centres also serve as the administrative centre for peer education programmes that perform outreach activities in the catchment areas, as well as advertise the Y-Centres.

Except for Sakhulutsha, most Y-Centres are in their beginning stages, having been opened in late 1999 to early 2000. All four operational loveLife Y-Centres were included in the study: Orange Farm Y-Centre in Gauteng, Sakhulutsha Y-Centre in Eastern Province, Kutlaonong Y-Centre in Free State and Acornhoek Y-Centre in Northern Province. loveLife has since opened two additional Y-Centres in Kwazulu Natal.

\section{DfID-UNFPA Youth and Adolescent Reproductive Health Programme (YARHP)}

DfID funds this programme but implementation is overseen by UNFPA. The goal of YARHP is to "improve the health status of South African youth and adolescents from the poorest sections of society," through "provision of cost effective reproductive health services for adolescents and youth in the poorest communities of Northern Cape, North West, and Northern Provinces" (Making Connections, 2001).

Technically, all sites are managed by DoH, with PPASA responsible for certain activities, such as health services, and accountable to DoH. YARHP targets young people aged 10 to 24. The guiding principles of the programme are to build on existing infrastructure and 
capacities, build partnerships, design programmes that are culturally coherent, and promote sustainability. The programme is operational in three provinces only, namely Northern Cape, North West and Northern Provinces.

After a preliminary situation analysis, the respective Provincial Departments of Health developed strategic plans for the promotion of reproductive health among young people. Each Department of Health made use of DfID funds to contract PPASA to undertake key tasks on its behalf. Central to all of the strategic plans was the deployment of government facilities (such as cultural centres, welfare centres and health centres) to support the development of youth friendly services. Typically, rooms have been rented, borrowed, or shared to provide reproductive health information, clinical services, counselling and life skills education for young people. While in many cases facilities are integrated, services are not. The clinical RH services are for young people only, even if adults use other parts of the facility. Recreation is offered at all the centres, though the scope and scale of these facilities is considerably more modest than loveLife Y-Centres.

All of the centres have peer education programmes that coordinate life skills workshops, conduct outreach activities and advertise the centres' existence. At the time of the study, only Thlokomelo centre in Kimberley was open on weekends. This centre, together with the Upington centre, also provides practical training for student nurses completing a youth and adolescent reproductive health training module. PPASA employees staff most of the centres, although assigned government employees also staff Northern Province centres.

Like loveLife Y-Centres, YARHP centres opened in late 1999 to early 2000. It is anticipated that after three years of support from DfID and UNFPA, the Provincial Departments of Health will either absorb the centres or continue to contract an NGO (such as PPASA) to provide specialized youth services. Six YARHP youth centres were selected for inclusion in the study. Two centres from each province were selected and, within the provinces, the Provincial Programme Committee selected sites that represented the range of models being tested. The centres selected were Mphambo and Moletsi Youth Centres in Northern Province, Thlokomelo and Upington Youth Centres in Northern Cape, and Mmabatho and Motswedi Youth Centres in North West Province.

\section{KwaZulu-Natal Department of Health Youth Clinics (KZN DoH)}

In 1985, the Department of Health and Population Development initiated a youth programme combining education, counselling and clinical services. In all, nine youth clinics were established in KwaZulu-Natal Province, two of which have since been closed. KZN DoH youth clinics target married and unmarried young people aged 10 to 20 and offer vertical reproductive health information and services, including contraceptive and STI services. Some of the KZN DoH clinics have peer educators that perform outreach activities while others do not.

Two out of seven KZN DoH centres were selected for this study. These centres were chosen as they were representative of the youth centres being implemented by KZN DoH and because they were among the longest running youth centres in the programme. Both centres are located in urban areas, with one, Commercial City Youth Clinic, located in the heart of Durban's commercial district. The other youth clinic, Empangeni, is housed within a provincial hospital. As this study was being conducted, the Empangeni Youth Clinic was in a period of decline, with no staff fully devoted to youth services and uncertainty as to whether the site would maintain a focus on young adults.

At the same time, this clinic does maintain a network of peer educators that perform outreach activities in schools and the community. Unlike the loveLife or the YARHP clinics, the focus of KZN DoH youth clinics is on RH counselling and services; no recreational or 
vocational activities are offered at the clinics. One KZN DoH Centre - Commercial City offers services on Saturday mornings, while Empangeni has no weekend hours.

\section{Content Of Youth Centre Programmes}

The content of youth centre programmes varies from centre to centre. At a minimum, most centres have reproductive health services as well as RH information and/or life skills. Programmes such as loveLife and YARHP also offer recreational facilities.

\section{Life Skills}

One major component of most of the youth centre programmes is lifeskills. WHO defines "lifeskills" as "abilities for adaptive and positive behaviour, that enable individuals to deal effectively with the demands and challenges of everyday life" (WHO, 1999). Lifeskills training utilized in these programmes covers topics such as human physiology, sexuality, HIV/AIDS, assertiveness training, sexual decision-making, and substance abuse. Life skills are imparted to young people either by officers specially hired for this purpose (with the designation "Youth Educator: Lifeskills" or Community Advisors) and/or by trained peer educators (PE).

Youth Educators and peer educators reach young people through workshops they organize or through one-on-one interactions. Initial recruitment of peer educators is through schools and existing community groups. In schools, teachers identify students who they feel show leadership potential and possess good communication skills. Peer educators who are out of school are recruited through existing youth clubs or recommended by community leaders. In order to become a peer educator in the loveLife and YARHP programmes, a young person must go through two rounds of lifeskills training. The first training covers the basic lifeskills topics and takes one week. Young people that show leadership potential in the initial lifeskills training are asked to become peer educators.

These selected youth undergo an additional week of advanced training. The advanced training focuses on reinforcing knowledge of topics covered in the basic course. In addition, peer educators are trained on facilitation, how to recruit young people, and how to conduct a lifeskills workshop. Each KZN DoH centre has a Community Advisor who undertakes health education in the centres and in neighbouring schools. Community Advisors are responsible for training peer educators. For KZN DoH peer educators, training is one week, as opposed to two. In all of the programmes, peer educators are unpaid volunteers.

\section{Reproductive Health Services}

At the time of the study, all centres offered RH services except for the loveLife Acornhoek Y-Centre, which was in the process of setting up services. The package of RH services offered at the centres is more or less uniform. All centres offer pills, injections and condoms. Female condoms are available at all loveLife Centres, at one KZN DoH Centre (Commercial City) and one YARHP centre (Thlokomelo).

STI diagnosis and treatment using syndromic management was available at all centres, except Orange Farm where the STI service was being set up at time of the study. All but two centres (Commercial City and Motswedi) performed pregnancy tests, with most centres using a urine dipstick test. While all centres performed HIV counselling, only three - Kutlaonong, Sakhulutsha, and Motswedi - conducted HIV testing. Only three centres, Motswedi, Commercial City, and Empangeni, had the capacity to perform pap smears and none of the centres offered obstetric care services. 
The supply of family planning methods, including condoms, at the youth centres appears to be good. Clinics reported no stock outs of contraceptives during the three months prior to survey. Erythromycin, a drug essential for syndromic management of STIs was out of stock in two clinics at the time of survey. Not all clinics had a penis model for condom demonstration and only three clinics had a female demonstration model. Though all centres had boxes or dispensers for condoms in public areas, such as waiting areas, no centre had a dispenser in private areas such as toilets.

\section{Recreational Services}

The scope and scale of recreational and vocational services varies across centres and across agencies. KZN DoH centres do not offer recreational or vocational services. YARHP centres offer somewhat modest recreational services such as board games. They also tend to organize activities and clubs that do not require much equipment, such a drama clubs, dance clubs, and choir. loveLife centres have somewhat more equipment for recreation and vocational training, including table tennis, equipment for cooking and sewing, basketball courts, and computers for skills training.

\section{STUDY RESULTS}

The background and lifestyles of young South Africans will be described using data collected from youth in the seven catchment areas of the centres. Though these young people are not necessarily representative of all South African youth, they are, effectively, the potential clients of youth centres in this study. The performance of youth centres will be reviewed, examining who comes to the centres, what services they receive, and how prepared staff is in the centres. The peer education programmes will be reviewed vis-à-vis performance and capacity of peer educators. Finally a comparison of centre attendees versus non-attendees will made, examining sexual experience, family planning, and condom use between the two groups.

\section{Adolescents' Lifestyles In Catchment Areas}

\section{School, Work and Family}

Only one percent (9) of males and three percent (20) of females aged 12 to 24 are married. The majority of adolescents in this age group ( 80 percent) are in school, with negligible differences between boys and girls, and about eight percent of these are working for pay while in school. Among those that are out of school, about three quarters are not working. Less than half of the adolescents are living with both parents (43 percent of boys and 37 percent of girls), with a considerable proportion (37 percent) living with their mothers, but not fathers or living with other relatives.

\section{Attitudes Toward Gender Issues}

Young people were read a series of statements regarding the roles of men and women in society and asked whether they agreed or disagreed with the statement (Table 3). On all issues mentioned except one, girls were significantly more likely to hold a gender equitable view than boys. Interestingly, while the experience of violence in intimate relationships is quite common (see The Nature of Sexual Relations), most respondents disapproved of hitting or beating an intimate partner. 
Table 1: Percentage of respondents who hold gender equitable attitudes, by topic and sex

\begin{tabular}{|l|c|c|c|}
\hline & $\begin{array}{c}\text { Boys } \\
(n=642)\end{array}$ & $\begin{array}{c}\text { Girls } \\
(n=720)\end{array}$ & $\begin{array}{c}\text { All } \\
(n=1362)\end{array}$ \\
\hline $\begin{array}{l}\text { Believe a wife should be able to ask her husband to help with } \\
\text { domestic duties or childcare }\end{array}$ & 59 & $76^{* * *}$ & 68 \\
\hline $\begin{array}{l}\text { Believe that the husband is not the sole decision maker on the } \\
\text { number of children a family will have }\end{array}$ & 64 & $75^{* * *}$ & 69 \\
\hline $\begin{array}{l}\text { Believe that when a girl says 'no' to sex, she does not sometimes } \\
\text { mean 'yes' }\end{array}$ & 62 & $80^{* * *}$ & 72 \\
\hline $\begin{array}{l}\text { Believe it is not OK for a man to hit or beat his wife when she flirts } \\
\text { with other men }\end{array}$ & 77 & 80 & 78 \\
\hline $\begin{array}{l}\text { Believe women should have the same opportunities as men to } \\
\text { hold leadership positions in government }\end{array}$ & 79 & $89^{* * *}$ & 84 \\
\hline $\begin{array}{l}\text { Believe that it is not OK for a boy to hit or beat his girlfriend if she } \\
\text { is unfaithful }\end{array}$ & 83 & $88^{* *}$ & 86 \\
\hline \begin{tabular}{l} 
Source: Catchment Area Survey \\
\hline
\end{tabular} & $* * * \mathrm{p}<0.001 ; * * \mathrm{p}<0.01 ; * \mathrm{p}<0.05$ \\
\hline
\end{tabular}

\section{Sexual Initiation}

Boys appear to initiate sex at an earlier age than girls. Sexual initiation was analysed using life table analysis ${ }^{1}$, which is often used when a considerable number of cases are censored or, in other words, the event of interest has not yet happened. Figure 1 shows the cumulative probability of having sexual intercourse by age and sex, among all young people in the sample. The median age at first sex for boys is 16.5 years, and for girls, 17.5 - a finding that is roughly consistent with DHS data for South Africa as a whole (Department of Health, 1998). Keeping in mind that some young people might not want to admit they have had sex, by age 20 , about one quarter of young people had not yet initiated sexual intercourse.

\footnotetext{
${ }^{1}$ Life table calculations give the probability of having had sex at age X, among those that have not yet had sex at age X-1. The figure shows the cumulative proportion of those having had sex at each age.
} 
Figure 1: Cumulative Probability of Having Sex, By Age and Sex

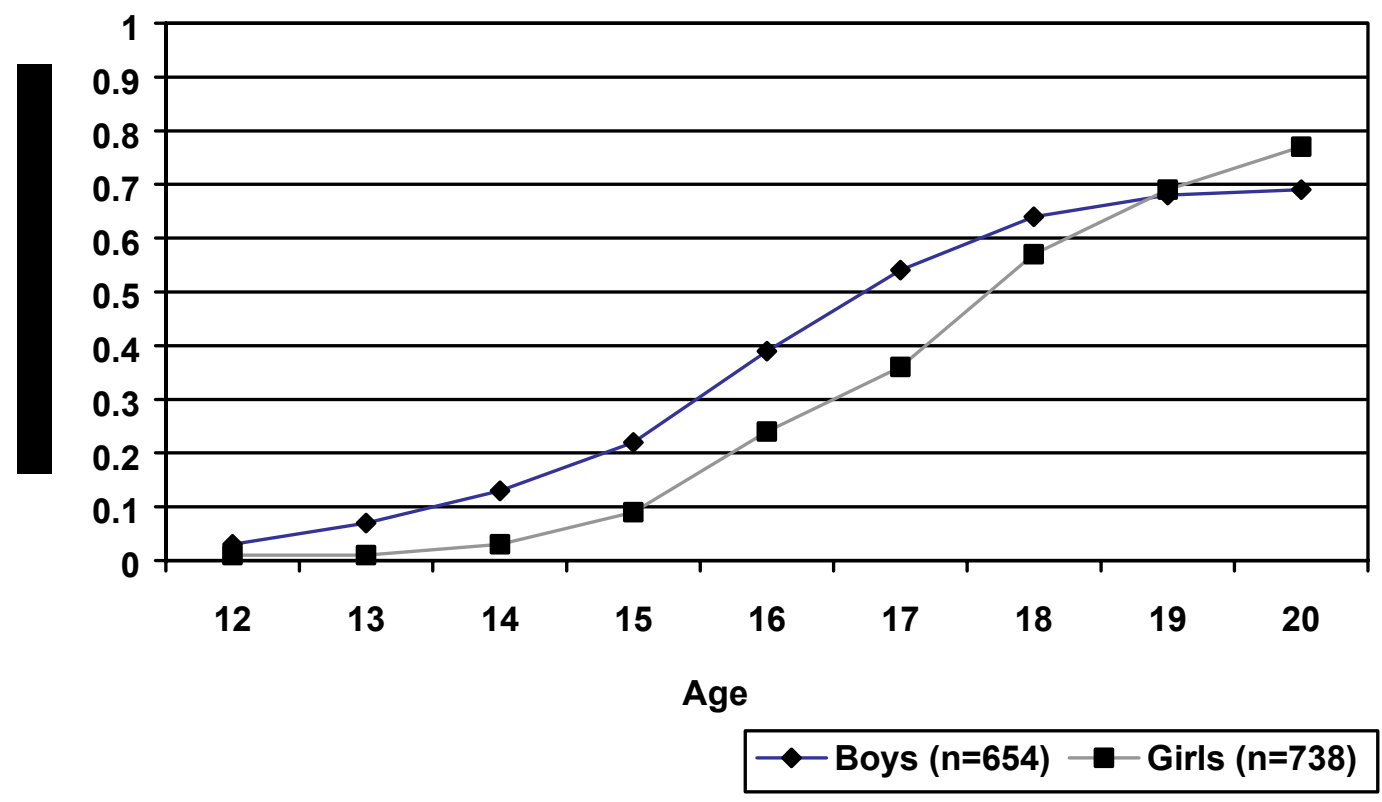

Source: Catchment area survey

\section{The Nature of Sexual Relations}

While boys were, on average, half a year older than their first sexual partner, girls were an average of over two years younger. Twelve percent of girls report they have ever been physically forced to have sex and 7 percent have been given money or gifts in exchange for sex. About one-third (34 percent) of girls have been hit by a partner, a further reflection of power imbalances within sexual relationships. In comparison, only 3 percent of boys reported that they had been physically forced to have sex and 1 percent say they have been given money or gifts in exchange for sex. The majority of girls (78 percent) with sexual experience have had one or two sexual partners; among boys, 44 percent have had one or two sexual partners and 54 percent have had more than two partners.

Sexual intercourse among adolescents is relatively infrequent, with about one-fifth of sexually experienced adolescents not having sex in the three months prior to survey and a minority of adolescents ( 23 percent of boys and 17 percent of girls) having sex six or more times in three months. By age 20, about one-third of all girls in the sample had experienced a pregnancy. Girls in the sample who had experienced pregnancy were, on average, 18.5 years when they became pregnant.

Between sexually active girls who get pregnant and those that do not, there is no significant difference in when sexual activity was initiated. In other words, girls who get pregnant are not necessarily those that start having sex when they are young. However, girls who experienced a pregnancy are significantly more likely to have experienced forced sex, offers of money or gifts in exchange for sex, and beatings by a partner, compared to sexually active girls who have not experienced a pregnancy. This finding is consistent with other studies conducted in South Africa (Jewkes, et. al., forthcoming). Thirteen percent of boys admitted to having made a girl pregnant; they were, on average 20 years old the first time they impregnated a girl. 


\section{Family Planning Use}

Of sexually experienced adolescents, 36 percent of boys and 26 percent of girls are not currently using a family planning method. Figure 2 reveals the type of family planning used among sexually experienced adolescents using a method. Ninety-one percent of boys and 22 percent of girls report use of condoms on their own. Twenty-nine percent of girls report injectable use only, while less than one percent of boys report that their partner is using the injectable. This discrepancy is likely due to many boys not knowing that their partner is using the injectable. Alternatively, boys might have interpreted questions on FP use to refer to methods that they are using personally, rather than methods used by either themselves or their partners. While only six percent of boys report dual method use, 40 percent of girls report using condoms and another method, which, again, suggests that many boys do not know, or do not report, that their intercourse is protected by more than a condom. Most of the dual method use reported by adolescents was condoms combined with injections (71 percent), followed by condoms and pills ( 24 percent).

\section{Figure 2: Method Choice Among Adolescents Using Family Planning}

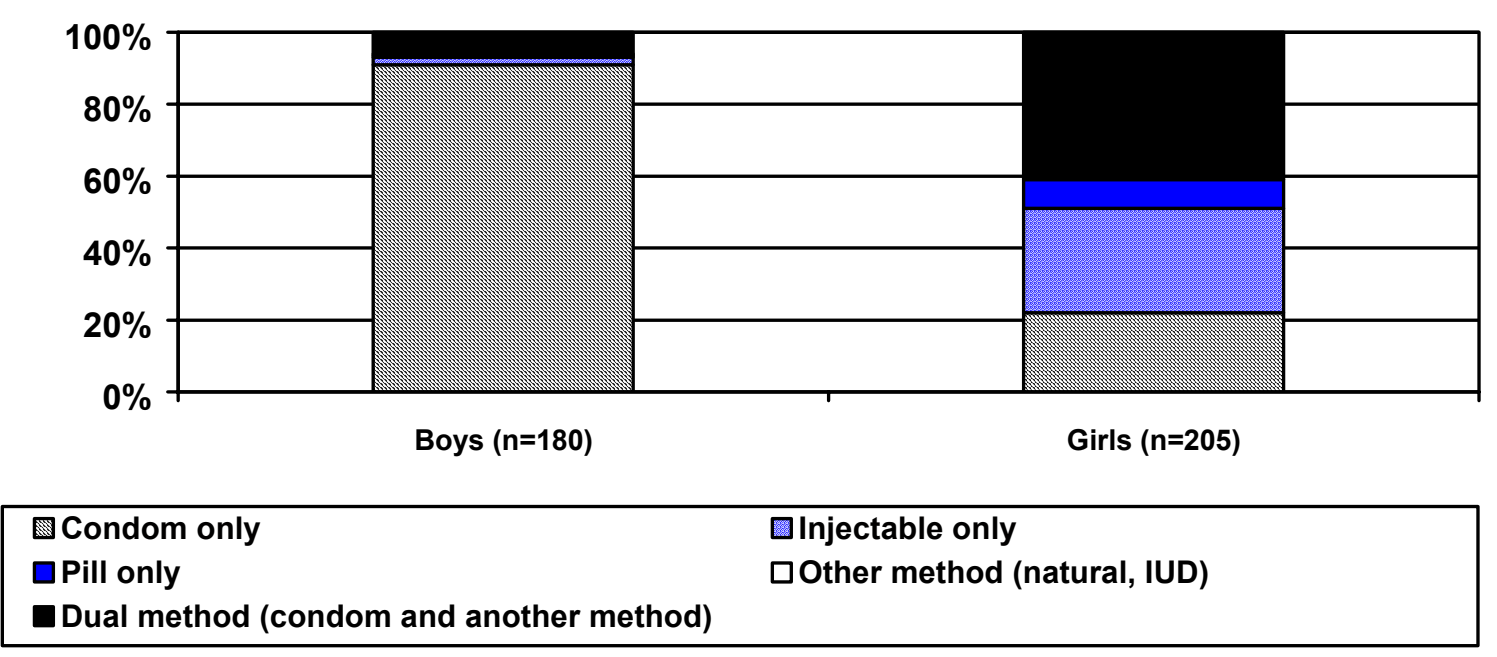

Source: Catchment area survey

\section{Condom Use}

Ever use of condoms among sexually experienced adolescents in the catchment areas is high ( 82 percent of boys and 70 percent of girls). Thirty-two percent of boys and 35 percent of girls had consistently used condoms during the last five acts of intercourse. The most common sources of condoms were public hospitals ( 63 percent), followed by youth centres (11 percent), friends ( 9 percent), and private clinics ( 8 percent). Young people getting condoms from public facilities and from youth centres more often take condoms from a dispenser or box than from health personnel (Figure 3). This suggests that condom dispensers are either more readily accessible to young people or that they prefer the anonymity of taking condoms than having to ask personnel for them.

When sexually experienced young people who had never used a condom were asked their main reason for non-use, the most common reason given was that they had a partner that they trust ( 27 percent of boys and 30 percent of girls). Respondents were also asked if there was ever a time that they had not used a condom when they had initially wanted to. Among boys, 
the most common reasons for not using condoms when they wanted to was not having them on hand (52 percent) and sex was not planned (22 percent). For girls, the main reason for non-use when they wanted condoms was that a condom was not on hand (42 percent) and that the partner did not approve of condom use ( 28 percent).

\section{Figure 3: Percentage of Youth obtaining Condoms from Dispensers and Clinic Personnel, by Type of Facility}

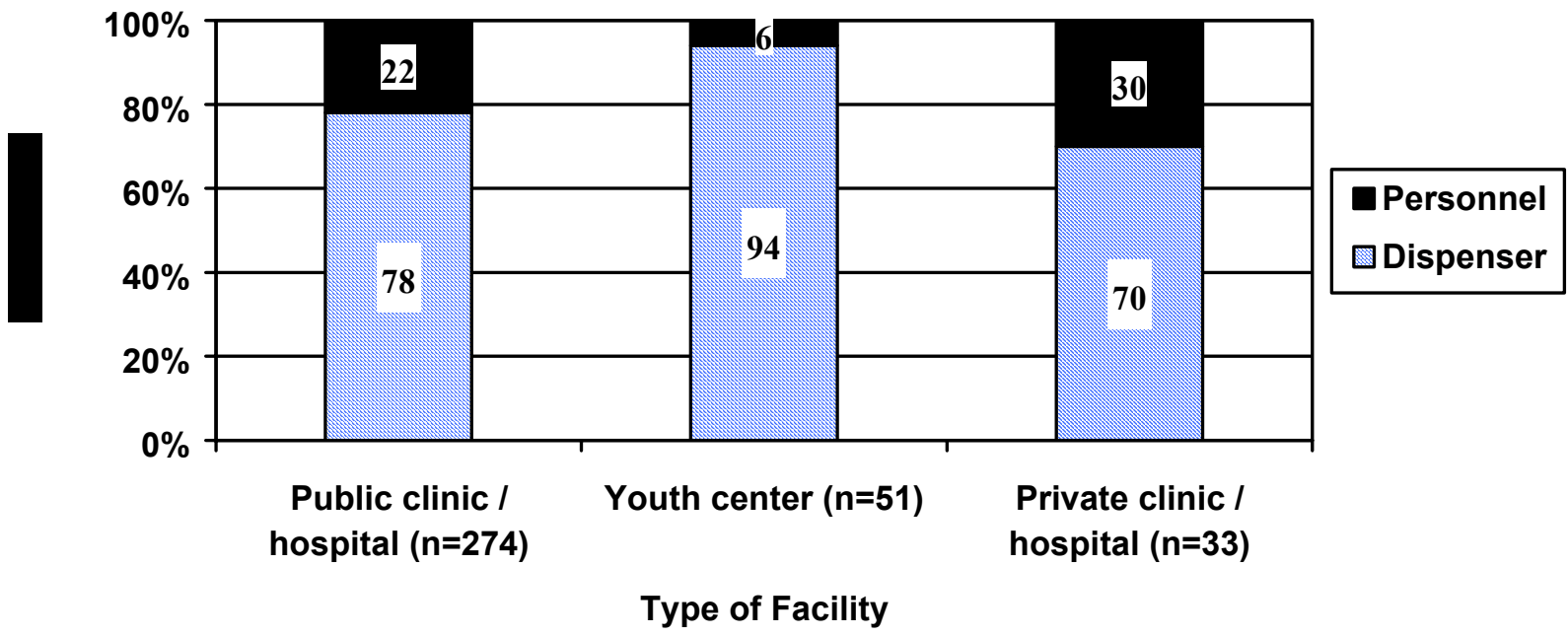

Source: Catchment Area Survey

\section{Reproductive Tract Infections}

Sexually experienced adolescents were asked if they had ever experienced a symptom of a reproductive tract infection (RTI), described as discharge, sores, or painful urination. Twenty percent of boys and 27 percent of girls had experienced at least one of these symptoms. Eighty-three percent of boys and 76 percent of girls sought assistance at the onset of these symptoms, the majority of whom (70 percent) went to public sector facilities. However, at the same time, almost one-fifth (17 percent) of boys sought assistance for a suspected RTI from a traditional healer. Among those seeking assistance, only a bare majority of their partners were referred for treatment (55 percent) with negligible differences between male and female respondents.

\section{Experience with AIDS Deaths}

South Africa has, reportedly, one of the highest prevalence of HIV infection in the world. Increasingly, young people are witnessing the effects of HIV in their own lives. Forty-three percent of youth know someone that has died of AIDS and 19 percent report that someone in their own family has died of AIDS.

\section{Preferences for Reproductive Health Services}

In the survey among young people ${ }^{2}$, sexually experienced respondents were read a list of thirteen qualities of RH services and asked them how important that quality was in their selecting a particular service. Responses were scored, with 10 points given if a respondent found a characteristic "very important", 5 points for "somewhat important" and 0 for "not important" (Table 2).

\footnotetext{
${ }^{2}$ Only sexually experienced young people were asked this question on the assumption that they would have more experience in seeking health services or a greater insight into the kind of services they would seek.
} 
Table 2: Mean scores of the importance of RH service characteristics, by sex

\begin{tabular}{|l|c|c|c|}
\hline Characteristic & Boys (n=278) & Girls (n=271) & All (n=549) \\
\hline Friendly staff & 8.3 & 9.1 & 8.7 \\
\hline Quick service / short waiting time & 8.3 & 8.8 & 8.5 \\
\hline $\begin{array}{l}\text { Service provider takes time during } \\
\text { consultation }\end{array}$ & 7.6 & 8.3 & 8.0 \\
\hline All services available in one facility & 7.2 & 7.8 & 7.5 \\
\hline Non-judgmental staff & 6.8 & 8.0 & 7.4 \\
\hline Low cost / free services & 7.2 & 7.3 & 7.2 \\
\hline Convenient hours & 6.8 & 7.6 & 7.2 \\
\hline Located close to home, school or work & 6.8 & 7.1 & 7.0 \\
\hline Youth work there & 6.0 & 6.9 & 6.5 \\
\hline Peer educators work there & 5.3 & 6.4 & 5.8 \\
\hline Specifically for youth & 4.7 & 5.4 & 5.1 \\
\hline The service provider is relatively young & 4.0 & 4.5 & 4.3 \\
\hline $\begin{array}{l}\text { Anonymity: Few people, including other } \\
\text { youth, know you }\end{array}$ & 3.4 & 4.3 & 3.9 \\
\hline Service provider is same sex as you & 2.9 & 3.9 & 3.4 \\
\hline Parents or other adults will not see you & 3.2 & 3.5 & 3.3 \\
\hline $\begin{array}{l}\text { Single sex: Girls only service (females); Boys } \\
\text { only service (males) }\end{array}$ & 1.3 & 1.1 & 1.2 \\
\hline
\end{tabular}

Source: Catchment Area Survey

The most important qualities in services for young people was that the staff were friendly, waiting times were short, the provider took their time during consultation, comprehensive services were available in one facility, the staff was not judgmental and services were low cost or free. Qualities that were relatively less important to young people - those with mean scores less than five - were that the service provider is young and the same sex, young people would not see people they know there or adults they know, and that the service is single sex. Interestingly, a youth-only service, which is a hallmark characteristic of youth centres, was not rated as highly important compared to other characteristics.

There was little variation between age groups, though those in the younger age group (12 to 15 years) considered not seeing their parents at the service somewhat more important than the older age groups. 


\section{Performance Of The Youth Centres}

\section{Awareness of and Exposure to the Centres}

Overall, 61 percent of youth in the catchment areas of the youth centres are aware of their existence and 29 percent have ever visited the centres. Awareness of centres varies considerably across centres and between sexes (Table 3 ).

In general, awareness of loveLife centres is relatively high, especially those that have been in existence for a longer period. The greater awareness of loveLife centres compared to YARHP centres could be due to loveLife centres being physically large structures that tend to be new and modern, and often contrasting with their low-income surroundings. There were no significant differences between those visiting and not visiting by age, school status or sexual experience. Among youth that were aware of the centres but who had never visited them, when asked the main reason for not visiting the centres, 46 percent of boys mentioned that they had no time, 27 percent said that they did not know enough about the centre, and 17 percent felt it was too far away.

Among girls, the most common reason for not visiting was that they did not know enough about the centre (43 percent), followed by lack of time (33 percent), with 16 percent feeling it was too far. Youth not visiting the centres for lack of time or knowledge suggests that they would potentially go if the hours were changed or if they knew more about the centres. Twenty-one percent of youth say they have gone to the centres and found then closed and 19 percent felt that the hours are not convenient for them.

The first source of information about the centres was friends ( 57 percent), followed by those who saw the youth centre while passing by (15 percent). It appears that outreach efforts have not drawn many youth to the centres, with only six percent hearing about the centres from youth centre staff, four percent from peer educators, and two percent from awareness campaigns in schools, churches, and other community venues. Among parents interviewed, 38 percent had heard of the youth centre. Among those who are aware of the centres, 17 percent have visited them. As with young people, parents living the catchment areas of loveLife centres were more likely to be aware of them (45 percent) compared to 20 percent of parents aware of the KZN DoH centre and 33 percent of parents aware of the YARHP centres.

\section{Table 3: Percentage of adolescents aged 12 to 24 who are aware of the youth centres and who have visited, by sex}

\begin{tabular}{|l|c|c|c|c|}
\hline & \multicolumn{2}{|c|}{ Boys } & \multicolumn{2}{c|}{ Girls } \\
\hline & Aware & Visited & Aware & Visited \\
\hline All Centres $(\mathrm{n}=1399)$ & 53 & 29 & 68 & 29 \\
\hline loveLife Acornhoek $(\mathrm{n}=192)$ & 62 & 47 & 65 & 40 \\
\hline loveLife Kutluanong $(\mathrm{n}=196)$ & 94 & 64 & 89 & 45 \\
\hline loveLife Sakhulutsha $(\mathrm{n}=201)$ & 82 & 27 & 80 & 26 \\
\hline loveLife Orange Farm $(\mathrm{n}=198)$ & 46 & 17 & 59 & 35 \\
\hline YARHP Thlokomelo $(\mathrm{n}=201)$ & 27 & 12 & 63 & 23 \\
\hline YARHP Upington $(\mathrm{n}=200)$ & 8 & 1 & 38 & 13 \\
\hline
\end{tabular}

Source: Catchment Area Survey 


\section{Profile of Youth Centre Visitors}

Visitors to the youth centres were registered during a one-week period in October 2000. The centres that have a wide range of recreational activities tend to attract more repeat visitors than those that those that focus on clinical services. Among visitors to loveLife centres, each youth had visited an average of four times during the previous seven days, ranging from 3 visits during the past week at Sakhulutsha, to over 5 visits at Kutluonong. Among YARHP centres, youth had visited an average of one time in the last week, with Mmabatho seeing clients making an average of 3.5 visits. There were virtually no repeat visits for the KZN DoH centres, probably because these centres focus on RH services only.

Repeat visitors were more likely to be male and young, and attending school. On average, male visitors to the youth centres had paid four visits to the centre in the previous week, compared to girls' two visits. The average age of those who visited the centres three or more times was 15.8 years, compared to an average age of 18.6 years, among those who had visited less than three times. Repeat visitors were most likely to come to the centres for sports or recreation, compared to the other services offered at the centres.

Registers collected information on youth centre visitors, not individuals, in order to get a sense of the level of activity at the centres. If a young person came three times during the week of data collection, he/she was registered three times. Since analysis of these data would be biased toward young people who were repeat visitors, data was weighted by the number of visits that individual young people made during the past week ${ }^{3}$. Visitors to the loveLife centres were fairly balanced in terms of gender (Table 4). The YARHP and KZN DoH centres tended to attract more girls than boys, perhaps because these centres are more focused on RH services than the loveLife centres.

The age range of young people targeted varies from programme to programme, and even within programmes. The target age range for three loveLife centres is 12 to 17 , with Orange Farm having a target age range of 10 to 20 . For KZN DoH centres the target age range is 10 to 20, and for DfID/UNFPA centres 12 to 24. A considerable proportion of visitors in the loveLife and KZN DoH centres were over the official target age. In virtually all centres, more than half of the clientele was sexually experienced, suggesting that many young people that come to the youth centres are potential RH service clients.

\footnotetext{
${ }^{3}$ Visitors to the youth centres were asked how many times they had visited the youth centres during the seven days prior to that particular visit. Assigned weights were the inverse of the number of visits made plus one. For example, a young person who had not visited the youth centre in the previous seven days was assigned the weight $1 /(0+1)$, or 1 . A young person who had visited the youth centre 7 times during the previous 7 days was assigned the weight $1 /(7+1)$, or 0.125 .
} 
Table 4: Characteristics of youth visiting the centres, by centre

\begin{tabular}{|c|c|c|c|c|c|c|c|c|c|c|}
\hline \multirow{2}{*}{ Centre } & \multirow{2}{*}{$\begin{array}{c}\text { Total } \\
\text { visits } \\
\text { in one } \\
\text { week }\end{array}$} & \multirow{2}{*}{$\begin{array}{l}\% \\
\text { First } \\
\text { visits }\end{array}$} & \multicolumn{2}{|c|}{ Sex } & \multirow{2}{*}{$\begin{array}{l}\text { \% in } \\
\text { school }\end{array}$} & \multirow{2}{*}{$\begin{array}{l}\text { Mean } \\
\text { Age }\end{array}$} & \multirow{2}{*}{$\begin{array}{l}\text { Target } \\
\text { Age } \\
\text { Range }\end{array}$} & \multirow{2}{*}{$\begin{array}{c}\% \text { Over } \\
\text { Target } \\
\text { Age } \\
\text { Range }\end{array}$} & \multicolumn{2}{|c|}{$\begin{array}{l}\% \text { Sexually } \\
\text { Experienced }\end{array}$} \\
\hline & & & $\mathbf{M}$ & $\mathbf{F}$ & & & & & $\begin{array}{c}\begin{array}{c}\text { Male } \\
(n= \\
152)\end{array} \\
\text { (1) }\end{array}$ & $\begin{array}{l}\text { Female } \\
(n=429)\end{array}$ \\
\hline$\frac{\text { loveLife }}{\text { 1. Acornhoek }}$ & 282 & 9 & 60 & 40 & 93 & 16.1 & $12-17$ & 25 & $-^{*}$ & $-{ }^{*}$ \\
\hline 2. Kutloanong & 437 & 9 & 46 & 54 & 97 & 15.2 & $12-17$ & 18 & 52 & 50 \\
\hline 3. Sakhulutsha & 476 & 18 & 37 & 63 & 80 & 17.9 & $12-17$ & 40 & 79 & 50 \\
\hline 4. Orange Farm & 363 & 6 & 54 & 46 & 83 & 16.8 & $10-20$ & 4 & 64 & 46 \\
\hline$\frac{\text { KZN DoH }}{\text { 1. Commercial City }}$ & 276 & 27 & 5 & 95 & 67 & 19.6 & $10-20$ & 14 & 86 & 90 \\
\hline 2. Empangeni & 39 & 23 & 5 & 95 & 44 & 22.3 & $10-20$ & 56 & 86 & 86 \\
\hline$\frac{\text { YARHP }}{\text { 1. Thlokomelo }}$ & 77 & 47 & 0 & 100 & 62 & 20.3 & $10-24$ & 6 & - & 92 \\
\hline 2. Moletshi & 60 & 39 & 22 & 78 & 66 & 19.1 & $10-24$ & 2 & 100 & 91 \\
\hline 3. Mmabatho & 33 & 16 & 21 & 79 & 80 & 18.6 & $10-24$ & 0 & 20 & 55 \\
\hline 4. Mphambo & 162 & 26 & 34 & 66 & 75 & 18.3 & $10-24$ & 8 & 55 & 54 \\
\hline 5. Upington & 121 & 28 & 16 & 84 & 43 & 20.2 & $10-24$ & 9 & 89 & 76 \\
\hline 6. Motswedi & 118 & 27 & 13 & 87 & 76 & 19.0 & $10-24$ & 8 & 67 & 77 \\
\hline
\end{tabular}

\section{Reasons for Visiting Youth Centres}

The majority of youth centre clients (93 percent) came for only one reason. Among those coming for multiple reasons, 75 percent came for recreation/sport/dance and another reason. Figure 4 displays the services young people received at the centres. In this analysis, if an adolescent received more than one service while at the centre, he/she was considered to have received the more formal or health-related service. For example, if a young person came for both recreation and clinical services, he/she was coded as a visit for clinical services; if he/she came for both recreation and lifeskills, he/she was coded as a lifeskills visit.

Most youth visiting loveLife centres came for recreation, followed by RH services, and life skills training. Given that KZN Department of Health centres focus almost exclusively on clinical services, the vast majority of visitors (97 percent) received clinical services or condoms. Among YARHP sites, a majority of visitors received clinical services or condoms (64 percent), with 22 percent involved in recreational or sports activities and 14 percent receiving life skills. The fact that clients for recreation dominate the loveLife centres to a greater extent than the YARHP centres is probably a reflection of the greater amount of equipment and range of activities at the centres, i.e. if you offer it, people will come and use it. Vocational training activities, such as computer training, which are offered in the loveLife centres, do not seem to reach a large number of young people, perhaps because of limits on the number of young people that can be accommodated by such classes.

Overall, eighteen percent of youth centre visitors came for lifeskills, peer education, or reproductive health information. Roughly equal percentages of male and female visitors came for lifeskills (16 percent of boys and 19 percent of girls). Those that came for lifeskills were virtually the same age as the clientele that did not: 17.1 years compared to 17.4 years. 
Lifeskills visitors tended to be in-school youth, with 19 percent of the in-school visitors coming for life skills compared to only 14 percent of the out-of-school visitors coming for the same reason.

Those coming for RH services were significantly more likely to be female, to be out of school, and to be older. The average age of clients who received clinical services was 19.5 years, compared to 17 years for those receiving only recreational inputs. Those that took condoms during their visit to the centre were significantly more likely to be out of school and older, a probable reflection that this group is more likely to be sexually experienced than their young, in-school counterparts. Boys were also more likely to take condoms than girls, a difference that was statistically significant.

Figure 4: Services Received During Client Visits

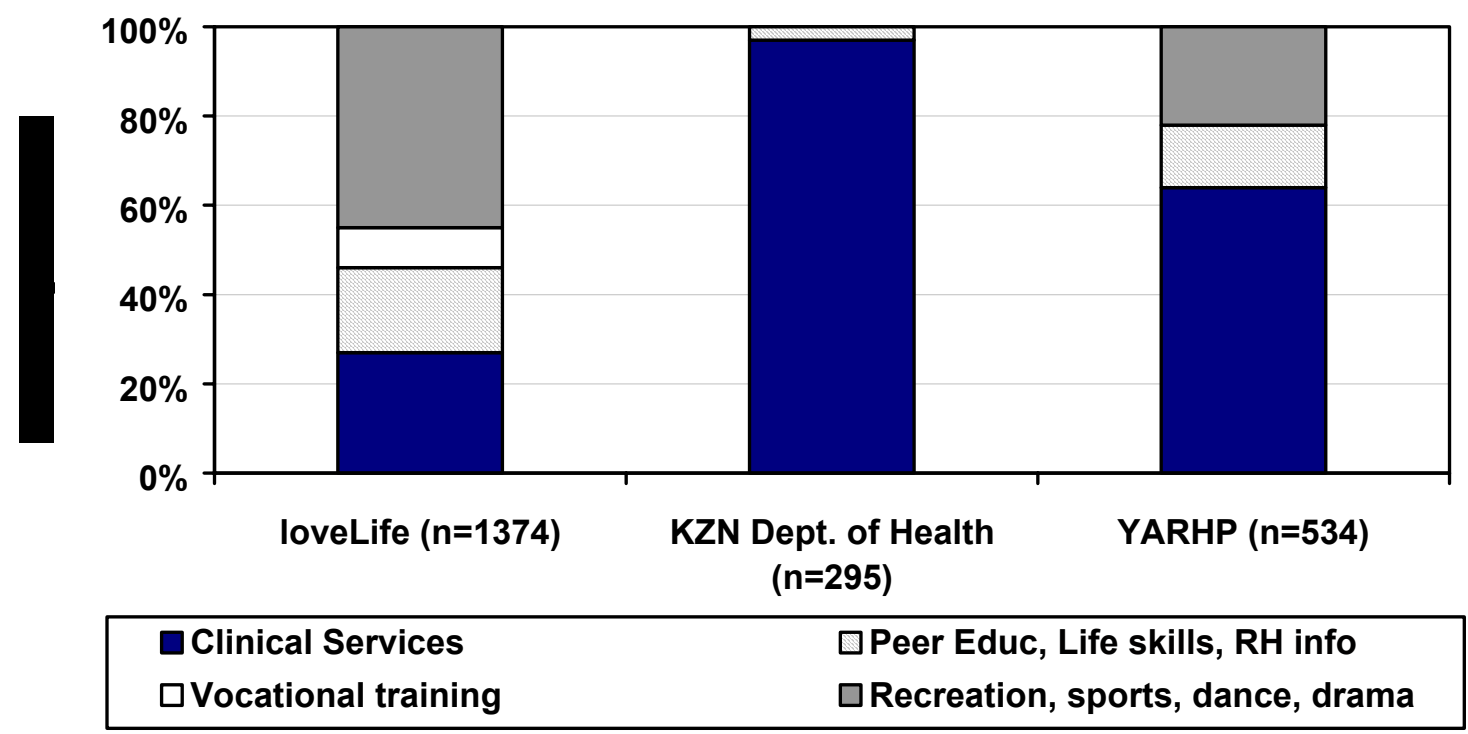

Source: Sign-in register 


\section{Clinical Services And Condom Distribution}

\section{Clinic Client Profile}

The magnitude and profile of clients receiving reproductive health services at the centres in one week is shown in Table 5. Commercial City (KZN DoH) saw the largest number of clients. This could be due to the popularity of the clinic or to the fact that there are three fulltime nurses, compared to most other clinics having one service provider, some of whom also perform outreach activities. The loveLife clinics had the lowest mean age of clinic clients compared to the other two models, which is likely a result of them having a lower target age group (with the exception of Orange Farm Y-Centre) compared to YARHP or KZN DoH centres.

When asked how clinics handle clients who are over-age, many nurses mentioned that the client is seen during the first visit but referred for subsequent visits to the adult clinic; others refer over-age clients to adult clinics when there is one in the vicinity. Still, a significant proportion of clients, especially in loveLife centres and KZN DoH centres are over the official age limit for the centre. Only 8 percent of clients seeing the nurse were male. This is probably due to female services, such as injectables, requiring regular visits.

Table 5: Characteristics of clients for clinical services

\begin{tabular}{|c|c|c|c|c|c|c|c|}
\hline & \multirow{2}{*}{$\begin{array}{c}\text { Total } \\
\text { visits in } \\
\text { one week }\end{array}$} & \multirow{2}{*}{$\begin{array}{l}\% \text { First } \\
\text { Visits }\end{array}$} & \multicolumn{2}{|c|}{ Sex } & \multirow{2}{*}{$\begin{array}{c}\text { Mean } \\
\text { Age }\end{array}$} & \multirow{2}{*}{$\begin{array}{c}\text { Age Range } \\
\text { of clients } \\
\text { seen }\end{array}$} & \multirow{2}{*}{$\begin{array}{c}\% \text { Over } \\
\text { Target Age } \\
\text { Range }\end{array}$} \\
\hline & & & $\%$ Male & $\%$ Female & & & \\
\hline$\frac{\text { loveLife }^{4}}{\text { 1. Kutloanong }}$ & 30 & 20 & 12 & 88 & 17.6 & $14-22$ & 52 \\
\hline 2. Sakhulutsha & 75 & 37 & 11 & 89 & 16.8 & $11-25$ & 55 \\
\hline 3. Orange Farm & 30 & 55 & 17 & 83 & 18.1 & $14-20$ & 0 \\
\hline$\frac{\text { KZN DoH }}{\text { 1. Commercial City }}$ & 219 & 17 & 0 & 100 & 18.6 & $14-36$ & 16 \\
\hline 2. Empangeni & 49 & 29 & 2 & 98 & 22.8 & $14-40$ & 59 \\
\hline$\frac{\text { YARHP }}{\text { 1. Thlokomelo }}$ & 50 & 29 & 4 & 96 & 20.0 & $13-27$ & 6 \\
\hline 2. Moletsi & 37 & 27 & 7 & 93 & 20.7 & $16-30$ & 3 \\
\hline 3. Mmabatho & 9 & 11 & 11 & 89 & 19.8 & $18-24$ & 0 \\
\hline 4. Mpambo & 86 & 45 & 19 & 81 & 18.3 & $11-24$ & 0 \\
\hline 5. Upington & 62 & 32 & 15 & 85 & 19.0 & $14-23$ & 0 \\
\hline 6. Motswedi & 55 & 40 & 7 & 93 & 20.6 & $16-23$ & 0 \\
\hline
\end{tabular}

Source: Nurse Register

\section{Patterns of Service Utilization}

The majority of clients coming for clinic services came for a family planning consultation (Table 6), followed by RTI services and counselling/health educations. While three centres reported that they do HIV testing - Kutlaonong, Sakalusha, and Motswedi - only Motswedi reported performing six HIV tests during the week of data collection.

\footnotetext{
${ }^{4}$ Acornhoek is not included as this centre did not offer clinical services at the time of the study.

${ }^{5}$ For counselling or health education sessions, in most cases, nurses did not record the content of counselling or information sessions.
} 
Table 6: Percentage ${ }^{6}$ of clinic clients receiving service from the nurse, by implementing agency and sex ${ }^{7}$

\begin{tabular}{|l|c|c|c|c|c|c|}
\hline Service & $\begin{array}{c}\text { loveLife } \\
\text { Centres } \\
(\mathbf{n = 1 7 4 )}\end{array}$ & $\begin{array}{c}\text { KZN DoH } \\
\text { Centres } \\
(\mathbf{n = 2 6 8 )}\end{array}$ & $\begin{array}{c}\text { YARHP } \\
\text { Centres } \\
(\mathbf{n = 2 9 8})\end{array}$ & $\begin{array}{c}\text { All } \\
\text { Boys } \\
(\mathbf{n = 5 4})\end{array}$ & $\begin{array}{c}\text { All Girls } \\
(\mathbf{n = 6 6 1 )}\end{array}$ & $\begin{array}{c}\text { All } \\
\text { Centres } \\
(\mathbf{n = 7 4 0}\end{array}$ \\
\hline Family Planning & 65 & 87 & 60 & 28 & 75 & 71 \\
\hline Reproductive Tract Infections & 12 & 11 & 14 & 32 & 11 & 13 \\
\hline Counselling/Health Education & 24 & 4 & 14 & 19 & 12 & 13 \\
\hline Primary Health Care * & 2 & 0 & 13 & 26 & 4 & 6 \\
\hline Pregnancy Test & 3 & 0 & 7 & 0 & 4 & 4 \\
\hline Referral to other SDPs & 5 & 1 & 5 & 2 & 3 & 3 \\
\hline Condoms & 2 & 2 & 3 & 19 & 1 & 2 \\
\hline
\end{tabular}

In terms of consultations for family planning, the injection was the most commonly provided family planning method followed by the pill (Figure 5). Few clients received condoms from the nurse and only four clients received dual protection from the clinics. The two-month injection, Nuristerate, was the most popular injection, with Depo-Provera far less common, a trend that is consistent with the current nationwide shift from the 3-month to the 2-month injection. It is not clear, however, whether this trend is because of availability or choice. The two KZN DoH clinics were commonly using Petogen, the South African-manufactured 3month equivalent to Depo-Provera. Emergency contraception was not well utilised at any clinic with only two clients receiving this service across all twelve youth centres during the week of data collection.

Figure 5: Contraceptive Method Mix, by Implementing Agency

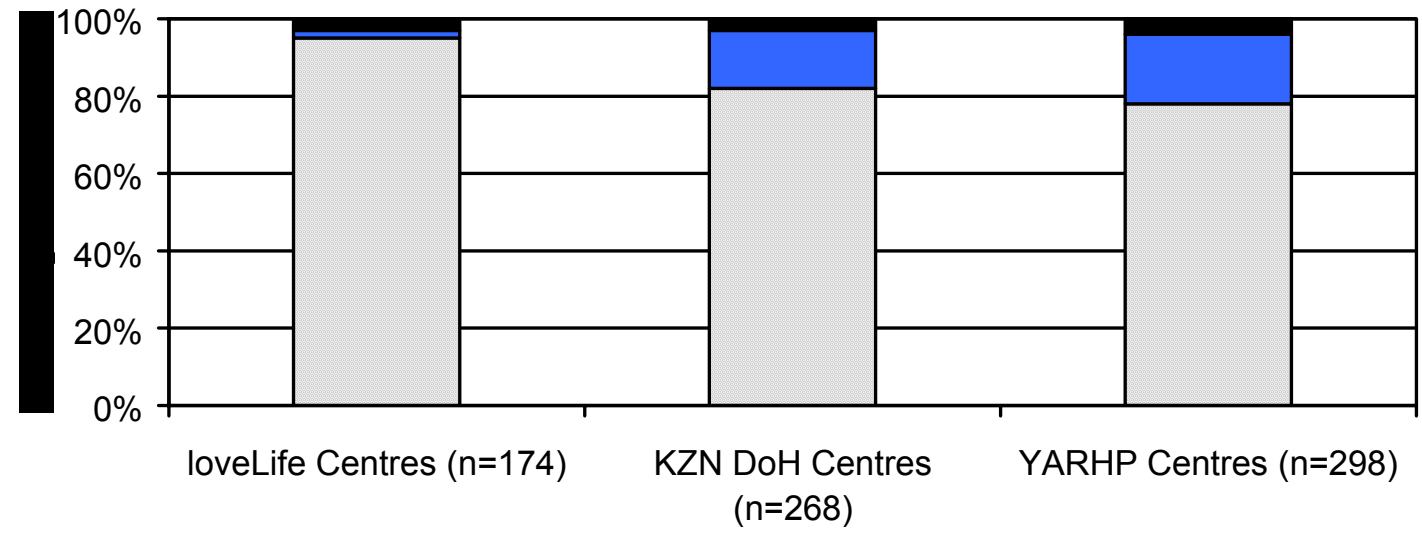

Youth center

Source: Nurse register

$\square$ Injection $\quad \square$ Pill $\quad$ Condom

\footnotetext{
${ }^{6}$ Percentages may sum to over $100 \%$ as more than one response was allowed.

${ }^{7}$ Numbers of boys and girls used in calculation do not sum to 740 total clients because of missing information on sex of client.
} 
As expected, the pattern of services was different for boys compared to girls. Girls were significantly more likely to receive family planning compared to boys; seventy-five percent of female clinic clients received family planning compared to 28 percent of males. Boys were significantly more likely to receive RTI services, condoms, and non-RH health care compared to girls.

Condoms were available in all clinics from a number of sources, including the nurse.

However, only two percent of clinic clients received condoms from the nurse and only one STI client received condoms from the nurse. Reasons for this could be that the nurse is referring the client to another source for condoms (such as a dispenser or box); that young people prefer to get condoms from other sources, or that condoms are not discussed during the session or not desired. At the same time, this study did not assess reasons why few nurses were giving condoms.

The source of condoms for youth centre clients was not necessarily the youth centres. Among youth centre clients interviewed on exit, just over half (52 percent) who had sex in the last three months and who used condoms, last obtained their condoms from the youth centre and 36 percent obtained them from public hospitals or clinics. The remainder obtained them from friends, private clinics, and shops. Comparing those that obtained condoms from the youth centre, versus those that did not, there were insignificant differences in terms of age, sex, school status, and frequency of visits to the centres. Moreover, among male youth centre clients who claimed not to have used a condom when they wanted to, 18 percent reported that their reason for non-use was lack of access to condoms. This suggests that some boys do not know that condoms are available at the centres, which is surprising given the emphasis on HIV prevention at the centres.

\section{Consultation Time and Duration}

Figure 6 reveals the percentage of clients seeing the nurse at various times during the day. At loveLife clinics, peak attendance is between three and four o'clock in the afternoon, which roughly coincides with after-school hours. In the YARHP centres the client flow is more evenly distributed throughout the day with a slight drop over the lunch time period. The KZN Department of Health clinics witness peak attendance at lunch hour. At all clinics, attendance declines at about 4 to $5 \mathrm{pm}$ which could simply reflect nurses going off duty and not taking any clients later in the day.

\section{Figure 6: Timing of Clinical Client Visits, by Implementing Agency}

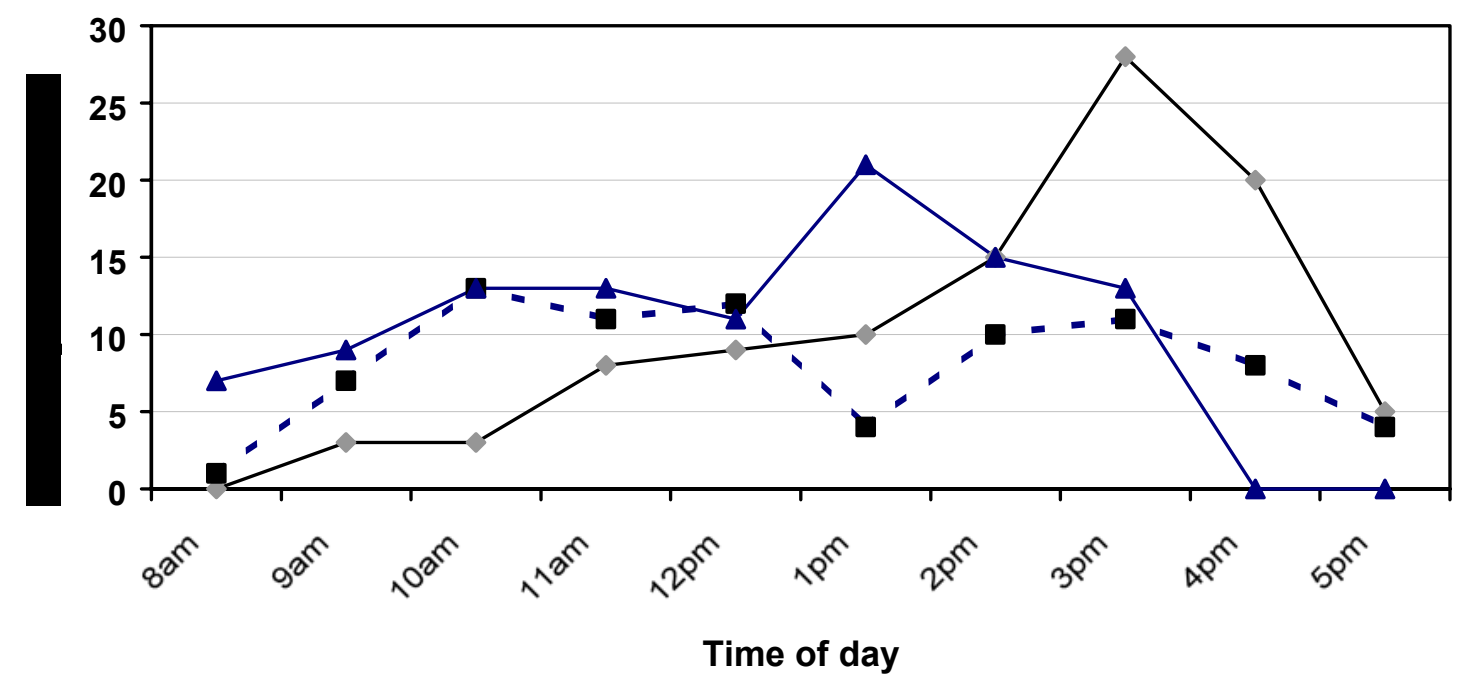

Source: Nurse register

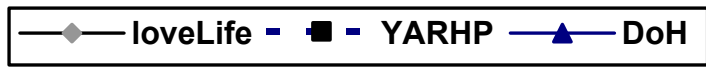


The longest consultations were those devoted to health information or counselling (Figure 7). The mean length of visits for STIs, pregnancy tests or the first family planning visits ranged from 10 to 13 minutes. The range of time spent with clients was wide. In some cases the STI visit was as low as five minutes, which is not adequate to complete the examination, treatment and counselling activities required by syndromic management guidelines, even if that visit is a follow-up. Therefore, it is not clear whether providers followed protocol for STI diagnosis, treatment or follow-up. Nurses recorded the timing and length of consultations during the week of data collection. It is also possible that busy nurses might have been less accurate in reporting the length of visits. The average length of condom visits were only 3 minutes, with roughly half of these being first visits.

Figure 7: Length of Consultation with the Nurse by Type of Visit

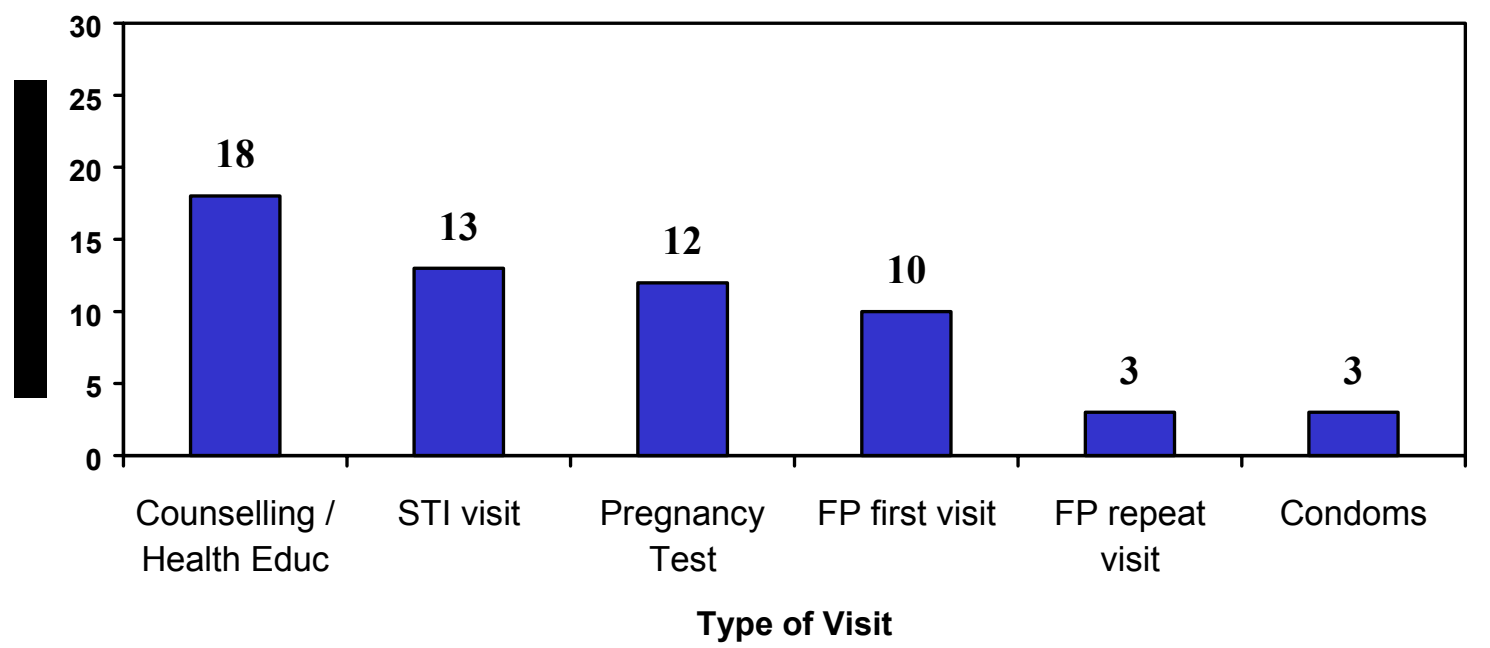

Source: Nurse register

\section{Provider Knowledge, Attitudes, and Counselling Skills}

The majority of providers were very knowledgeable on matters concerning RTI diagnosis and treatment. When asked how they would treat a number of typical STI symptoms including penile urethral discharge, vaginal discharge and genital ulcer (male or female), in over 80 percent of cases the provider reported the correct syndromic treatment, consisting of a combination of drugs. In some instances the provider listed some of the required drugs but not all drugs necessary for that particular syndrome. All providers know the correct timing and dosage when providing emergency contraception.

The vast majority of providers held liberal attitudes regarding young people's access to RH information and service. To determine providers' attitudes, they were read a list of six statements and asked whether they agreed or disagreed (for list of statements, see section Peer Educator Knowledge, Attitudes, and Interactions with Young People, Table 11).

All providers felt that life skills education and RH services would lead to a decrease in teen pregnancy and incidence of STIs. Of the nineteen providers interviewed, only two felt that young people should get parental consent before obtaining RH information or services. In addition, two providers felt that providing RH services to adolescents leads to increased promiscuity. 
In order to gauge nurses' counselling skills, providers were given a number of consultation scenarios and asked what they would say and/or do in response to such a situation ${ }^{8}$. For example, providers were asked what they say or do in the case of a 14 year-old girl requesting contraception. Almost all nurses described that they would counsel the girl on family planning. A few mentioned that they would first advise abstinence:

I would give her information about different family planning methods and teach her about STIs and HIV/AIDS, and about teenage pregnancy, and let her make an informed choice.

If the girl has not yet had sex, she will get counselling to reconsider starting sex in the light of STD exposure. If she is going to start or has already had sex, she will be counselled for a method and advised to use condoms.

In another scenario, a 14 year-old boy asks for condoms. Most providers describe providing them freely, along with information on their importance and how to use them:

I will give information and demonstrate the condom. I appreciate this. I will provide him with condoms. I would also find out how much he knows.

I will teach him how to use condoms and the importance of using it.

Provider responses also supported the finding that young people prefer to get condoms from dispensers or are encouraged to:

Boys don't often come to the nurses. If they come to me, I would tell them to delay [sex] but we do give them condoms.

Boys can get condoms from the box dispenser but if they talk to a nurse, they will get them from her directly and will be told how to use them.

Providers were asked how they would advise a girl who was pregnant and considering termination of pregnancy (TOP), which is legal in South Africa. In many cases the providers were not comfortable in referring the girl without first trying to change her mind to continue with the pregnancy:

[I would] give counselling showing that she can keep the baby and give her other options [such as] fostering. I would ask about gestation. I would also explain that TOP is the last option but she should tell somebody - a friend, boyfriend, mother. Then [I would] refer her.

The majority would however refer her to the appropriate service and were neutral in their advice:

Firstly I would ask her how far she is with the pregnancy... counsel her and refer, also advise her on family planning use after TOP.

\footnotetext{
${ }^{8}$ Investigators preferred to use hypothetical situations rather than observation so as to prevent intruding on client-provider sessions, many of which might be sensitive, particularly for adolescents. Responses to these questions are likely to be biased towards what the provider believes to be the best response, so it is unlikely that actual practice will be better than the hypothetical response given.
} 


\section{Client Perceptions of the Provider}

Youth ${ }^{9}$ who had consultations with nurses in the youth centres had largely favourable views of the nurse and of their interaction with him/her. The overwhelming majority of clients found the nurses friendly, respectful and sympathetic. About one-third of youth seeing the nurses found them judgmental and about 14 percent felt the nurse was embarrassed during the interaction. Similarly, the dynamics during consultation were favourably viewed. However, roughly one-third of clients did not ask all the questions he/she had wanted and wished that they had more time with the provider. Ninety-seven percent of clients said they would use the service again and 93 percent felt all details of the consultation would be kept confidential.

\section{Performance Of Peer Educators}

\section{Peer Educator Profile}

At the time of data collection, seven centres had fully trained and operational peer education programmes. There is an equal balance of male ( 47 percent) and female peer educators (53 percent), a balance that is consistent across all agencies. The vast majority are not married and not living with a partner; only 5 peer educators of 108 surveyed are married or cohabitating. Peer educators ranged in age from 10 to 40 years, with two-thirds ( 66 percent) aged 20 years and younger and 12 percent aged 25 or older.

\section{Peer Educator Activities}

In loveLife and YARPH programmes, peer educators undergo two rounds of training - basic training and advanced training - before they become operational. The KZN peer educators undergo five days of training before being certified as peer educators. All peer educators are trained by designated staff. In the case of loveLife and YARPH centres, they are trained by Youth Educators; for KZN DoH centres, peer educators are trained by a Community Advisor who is overall responsible for health education in the clinic. After training, they are expected to conduct lifeskills education and workshops in the centres, in the communities, and in schools. All peer educators work on a voluntary basis. Few programmes stipulate the number of hours or days that peer educators should devote to the programme. Only two programmes - Kutloanong and Sakalusha - set targets for the number of hours that peer educators should work in a week - 10 hours per week at Kutloanong and 15 hours per week at Sakhulutsha. A considerable number of peer educators drop out of the programme after training. In total, 526 peer educators had been trained in the previous year with nearly half (247) dropping out of the programme in the course of the year.

Peer educators estimated that they spend an average of eight hours per week on peer education duties. Peer educators appear to spend slightly more time working in the centres than in the communities. loveLife peer educators spend an average of over five hours per week working at the centre and three and a half hours performing outreach. Department of Health peer educators spend nearly 4 hours at the centres and nearly three hours in outreach, while YARHP peer educators spend over four and a half hours at the centres and over three and a half in outreach. Nineteen percent of peer educators spend no time in outreach activities. When asked to estimate how they spend their time devoted to the programme, peer

\footnotetext{
${ }^{9}$ Perceptions of the nurse counselor were asked of young people in the catchment area survey who had seen the nurse $(n=100)$ as well as clients on exit from the centres $(n=409)$. Current clients (those interviewed on exit) are more likely to have had favorable views of the service. Clients who chose not to come back to the service because of dissatisfaction are not captured in the clinic setting. While there was little difference in the satisfaction level of clients in the catchment area compared to those in the clinics, data from the catchment area survey only were used as they would be more representative of client views.
} 
educators estimate that about half their time is devoted to giving lifeskills/RH training. A significant proportion of time is spent facilitating recreational activities (28 percent in loveLife, 13 percent in KZN DoH programmes, 29 percent in YARHP), or in support activities at the centres such as cleaning (12 percent at loveLife, 9 percent at KZN DOH, 8 percent at YARHP). Most peer educators reported distributing condoms as part of their activities. Seventy-five percent of loveLife peer educators reported that they distribute condoms; 71 percent of KZN DoH and 80 percent of YARHP PEs distribute condoms. It is more common for male peer educators ( 82 percent) to distribute condoms than female peer educators (71 percent). However, when asked whether they had any on hand for distribution, only 24 percent of peer educators who said they distribute condoms were carrying condoms for distribution at the time of interview.

\section{Peer Educator Performance}

The performance of peer educators seems to vary considerably, both between programmes and among peer educators themselves (Table 7). The mean number of contacts per peer educator in a week ranged from 5 in Empangeni to 42 at Moletsi. Within programmes there was further variability between peer educators. For example, peer educators in Moletsi contacted as few as 5 young people in a week and as many as 97 young people during the same period. In most centres, the majority of young people contacted by peer educators were in school. With the exception of Thlokomelo and Empangeni, the majority of contacts made were in a group setting, rather than an individual encounter.

The most common topics covered by peer educators were STIs (29 percent of contacts), teen pregnancy (21 percent), condoms (19 percent), HIV/AIDS (17 percent) and family planning (17 percent). Peer educators were significantly more likely to talk to boys about STIs and HIV/AIDS, compared to girls, while they were significantly more likely to talk to girls about family planning methods. loveLife PEs discussed HIV/AIDS in only 10 percent of contacts compared to 22 percent of KZN DoH PE contacts and 24 percent of YARHP PE contacts. Similarly, teen pregnancy was only discussed in 14 percent of loveLife contacts, compared to 31 percent of KZN DoH contacts and 26 percent of YARHP contacts. YARHP PEs discussed condoms in only 12 percent of contacts compared to 26 percent of loveLife contacts and 28 percent of KZN DoH contacts.

Table 7: Number and profile of peer educator contacts during one-week period

\begin{tabular}{|c|c|c|c|c|c|c|c|}
\hline \multirow{2}{*}{ Centre } & \multirow{2}{*}{$\begin{array}{l}\text { Ave. No. and } \\
\text { Range of } \\
\text { Contacts in } \\
\text { one week }\end{array}$} & \multirow{2}{*}{$\begin{array}{l}\text { Mean } \\
\text { Age of } \\
\text { Contacts }\end{array}$} & \multicolumn{2}{|c|}{$\begin{array}{l}\text { Contacts } \\
\text { by Sex }\end{array}$} & \multirow{2}{*}{$\begin{array}{l}\% \text { in } \\
\text { School }\end{array}$} & \multicolumn{2}{|c|}{$\begin{array}{l}\text { Type of } \\
\text { Contact }\end{array}$} \\
\hline & & & $\% \mathrm{M}$ & $\% \mathrm{~F}$ & & $\begin{array}{l}\% \\
\text { Ind }\end{array}$ & $\begin{array}{c}\% \\
\text { Grp }\end{array}$ \\
\hline $\begin{array}{l}\text { loveLife } \\
\text { 1. Kutloanong (11 PEs; } n=231 \text { contacts) }\end{array}$ & $21(5-29)$ & 16.4 & 32 & 68 & 90 & 10 & 90 \\
\hline 2. Sakhulutsha (9 PEs; n=261 PE contacts) & $29(11-60)$ & 15.9 & 43 & 57 & 87 & 23 & 77 \\
\hline 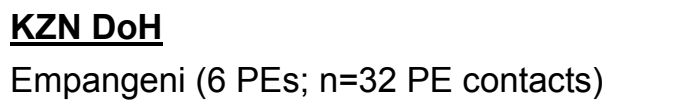 & $5(2-10)$ & 17.4 & 62 & 38 & 53 & 56 & 44 \\
\hline $\begin{array}{l}\text { YARHP } \\
\text { 1. Thlokomelo (12 PEs; } n=75 \text { PE contacts) }\end{array}$ & $6(2-13)$ & 19.4 & 48 & 52 & 64 & 75 & 25 \\
\hline 2. Moletsi (6 PEs; $n=251$ PE contacts) & $42(9-97)$ & 20.5 & 39 & 61 & 46 & 16 & 84 \\
\hline 3. Mphambo (3 PEs; $n=68$ PE contacts) & $23(6-55)$ & 16.6 & 58 & 42 & 71 & 15 & 85 \\
\hline 4. Motswedi (6 PEs; $n=146$ PE contacts) & $24(1-112)$ & 16.4 & 55 & 45 & 75 & 14 & 86 \\
\hline
\end{tabular}

Source: Peer educator register 


\section{Peer Educator Knowledge, Attitudes, and Interactions with Young People}

Peer educators were asked a series of questions to assess their knowledge on reproductive health issues (Table 8). They were highly knowledgeable on issues related to HIV/AIDS, while their knowledge was, at times, weak on matters related to fertility and family planning.

Table 8: Percentage of peer educators with correct reproductive health knowledge $(n=53)$

\begin{tabular}{|l|c|}
\hline & $\%$ \\
\hline Knew the fertile period during a woman's cycle & 11 \\
\hline Knew what a girl should do if she forgets to take the pill one day & 41 \\
\hline Knew a girl who has injections will not find it more difficult to get pregnant later on. & 44 \\
\hline Knew it is possible for a girl to get pregnant if the boy withdraws before ejaculation. & 53 \\
\hline $\begin{array}{l}\text { Knew that if one or one's partner has a sexually transmitted disease, this increases the } \\
\text { chance of transmitting HIV. }\end{array}$ & 83 \\
\hline Knew a man cannot always tell if a woman has a sexually transmitted disease. & 84 \\
\hline Knew that condoms are effective protection against HIV/AIDS transmission. & 92 \\
\hline Knew a girl can get pregnant the first time she has sex. & 93 \\
\hline $\begin{array}{l}\text { Knew that having a sexually transmitted disease makes it easier for one to contract } \\
\text { HIVIAIDS. }\end{array}$ & 93 \\
\hline Knew one cannot get HIVIAIDS from mosquito bites. & 95 \\
\hline Knew a healthy looking person can be infected with HIVIAIDS. & 96 \\
\hline Knew one cannot get HIVIAIDS by hugging a person with HIVIAIDS. & 96 \\
\hline Knew that having sex with a virgin cannot cure HIVIAIDS. & 96 \\
\hline
\end{tabular}

Source: Staff and peer educator interview

Regarding attitudes toward RH information and services for young people, peer educators were generally 'liberal' in their thinking, with the vast majority feeling that such services benefit their health and probably lead to a decrease in negative RH outcomes (Table 9). However, roughly one-quarter of peer educators felt that $\mathrm{RH}$ information and/or services could lead to sexual promiscuity an attitude that could impact upon their contacts with young people. 
Table 9: Percentage of peer educators holding "liberal” attitudes of RH information and services for young people

\begin{tabular}{|l|c|c|c|c|}
\hline & $\begin{array}{c}\text { loveLife } \\
\text { (n=55) }\end{array}$ & $\begin{array}{c}\text { KZN } \\
\text { DoH } \\
\text { (n=7) }\end{array}$ & $\begin{array}{c}\text { YARHP } \\
\text { (n=46) }\end{array}$ & $\begin{array}{c}\text { All } \\
\text { (n=108) }\end{array}$ \\
\hline $\begin{array}{l}\text { Providing adolescents with RH services does not } \\
\text { lead to promiscuity }\end{array}$ & 75 & 86 & 70 & 73 \\
\hline $\begin{array}{l}\text { Providing adolescents with RH information does not } \\
\text { lead to promiscuity }\end{array}$ & 80 & 71 & 74 & 77 \\
\hline $\begin{array}{l}\text { Adolescents should not need the consent of parents } \\
\text { when obtaining RH information or services }\end{array}$ & 73 & 71 & 85 & 78 \\
\hline $\begin{array}{l}\text { Better sexuality and life skills education and RH } \\
\text { services would probably lead to a decrease in teen } \\
\text { pregnancy, STIs, and HIV/AIDS }\end{array}$ & 91 & 86 & 94 & 92 \\
\hline $\begin{array}{l}\text { Young people need to be given RH information and } \\
\text { services to protect their health }\end{array}$ & 98 & 100 & 94 & 96 \\
\hline
\end{tabular}

Source: Staff and peer educator interview

In order to gain an understanding of peer educators' interactions with young people, we asked a series of hypothetical questions regarding how peer educators would react when faced with specific circumstances. For example, peer educators were asked, "Suppose a girl of 14 tells you about a situation. She has decided to have sex with her boyfriend and wants a family planning method. What would you say and do in this case?" Peer educators' reporting of how they would respond in this instance is extremely varied. Roughly half of peer educators described that they would advise abstinence and provide information only if the young person was persistent:

Firstly, I would convince her that sex is not good [at this] age, but if I realize that she is so much into this, I would provide methods. (loveLife centre, female)

She is very young. I would advise her to stop everything. She must abstain. If she has already done it, she must have one partner; she must use condoms. I would take her to the youth centre to attend workshops and learn more about relationships and sex. (loveLife centre, female)

Roughly one-third of peer educators would provide information and referral freely without revealing personal biases. Below are examples that are typical of these responses:

Sex depends on whether you like it or not, but I will advise her to use condoms and also contraceptives, especially injection. (loveLife centre, male)

I would give all reproductive health information and tell her about different family planning methods and refer her to the sister (YARHP centre, male)

About a fifth of peer educators would unequivocally advise abstinence and not provide any information on family planning, condoms or referral:

She is too young to have sex. She must forget about it. (KZN DoH centre, female)

[I would] suggest that she wait a while. Don't rush to have sex. I [would] tell her that sex after marriage is always the best. (loveLife centre, female) 
In another scenario presented to peer educators, a boy of 14 approaches the peer educator requesting condoms. About half of the peer educators described providing condoms and information on how to use them:

I would give the boy what he wants because I don't want to see him dying of HIV/AIDS. (loveLife centre, female)

I would give to him if they were available. (loveLife centre, male)

As with family planning methods, many peer educators would dissuade a young person who requests condoms from having sex, a response that effectively creates an additional barrier between young people and condoms:

I will start by asking why is he taking condoms and if the reason is good for me, I will allow him to take the condoms but making him aware that he is still young. (YARHP centre, female)

I will ask him what is he going to do with it but if the answer is right whether he know how to use the condom I will give him. (loveLife centre, female)

Eight peer educators described that they would refuse to give the boy condoms:

I will tell him he is still young to have sex and the best method is to abstain and further his education. I won't give him condoms. (YARHP centre, male)

Peer educators' responses to hypothetical scenarios often revealed personal biases, in particular, a bias towards abstinence. Such personal biases effectively create barriers to RH information and services, rather than remove them, and could dissuade a young person from pursuing services when they need them. While their responses could have been a reaction to the fact that the young person in the scenario is very young, the programmes in which they work make no age restrictions on access to family planning methods and condoms.

\section{Clients' Perceptions of Peer Educators}

Young people who had contact with peer educators had largely positive experiences. The vast majority of youth found peer educators respectful, friendly and sympathetic. About onequarter of young people found them judgmental and 15 percent perceived that they were embarrassed. In their interactions with the peer educator, about one quarter wished they had more time with the peer educator and one-fifth had questions or topics that were not covered during the session.

Peer educators are trained to cover sensitive subject matters related to sex, and, indeed, the philosophy behind peer education is that young people feel more comfortable talking to a peer about sensitive issues than they do to older people (Kerrigan and Weiss, 2000). In fact, when young people were asked the preferred age of a peer educator, 75 percent reported they would prefer a peer educator older than themselves and only 20 percent preferred a peer educator to be their own age. 


\section{COMPARING YouTh WHO Go To CENTRES AND THOSE WHO Do NoT}

In order to estimate the effect of the youth centre programmes on young people in the catchment areas, we divided young people into two groups: those that have been to the centre in the last three months and than those that have never been to the centres ${ }^{10}$. Our aim was to ascertain whether those that had been to the centres were "better off" in terms of RH knowledge, and safer sex behaviour, than those that had not been to the centre ${ }^{11}$.

Youth who had been to the centres at least once in the last three months numbered 314, compared to 852 young people who had never been to their local youth centre. Those that had been to the centre did not differ from those that had not in terms of age, sex or school status. The average age of those that had visited was 17.1, compared to those who had not visited, 17.4; among those that had been to the centres 83 percent were in school; among those who had not been to the centres, 80 percent were in school. Among those visiting the centres in the last three months, 54 percent were female; similarly among those never having visited the centre, 54 percent were female. This suggests that there was little or no selectivity bias in terms of demographic variables between those going or not going to the centres.

Table 10: Comparison of RH knowledge between youth who have been to the centres in the last 3 three months compared to those who have never been

\begin{tabular}{|c|c|c|}
\hline & $\begin{array}{l}\text { Never been to } \\
\text { the centre } \\
(n=847)\end{array}$ & $\begin{array}{l}\text { Been to the centre } \\
\text { in the last three } \\
\text { months }(n=314)\end{array}$ \\
\hline Knew the fertile period during a woman's cycle & $19^{*}$ & 14 \\
\hline $\begin{array}{l}\text { Knew a girl who has injections will not find it more difficult to get } \\
\text { pregnant later on. }\end{array}$ & 29 & 33 \\
\hline $\begin{array}{l}\text { Knew a man cannot always tell if a woman has a sexually } \\
\text { transmitted disease. }\end{array}$ & 50 & 56 \\
\hline Knew one cannot get HIVIAIDS from mosquito bites. & 64 & 65 \\
\hline Knew a girl can get pregnant the first time she has sex. & 67 & 63 \\
\hline $\begin{array}{l}\text { Knew that if one or one's partner has a sexually transmitted disease, } \\
\text { this increases the chance of transmitting HIV. }\end{array}$ & 75 & 77 \\
\hline $\begin{array}{l}\text { Knew that having a sexually transmitted disease makes it easier for } \\
\text { one to contract HIVIAIDS. }\end{array}$ & 76 & 75 \\
\hline Knew that having sex with a virgin cannot cure HIVIAIDS. & 83 & 84 \\
\hline Knew a healthy looking person can be infected with HIVIAIDS. & 84 & 84 \\
\hline $\begin{array}{l}\text { Knew that condoms are effective protection against HIVIAIDS } \\
\text { transmission. }\end{array}$ & 88 & 89 \\
\hline Knew one cannot get HIVIAIDS by hugging a person with HIVIAIDS. & 88 & 89 \\
\hline
\end{tabular}

\footnotetext{
${ }^{10}$ Young people who had been to the centres but who had not been there in the last three months were removed from analysis because we wanted to include only those that had a recent exposure to the centres.

${ }^{11}$ For this analysis, the catchment area data from Commercial City was removed as few respondents in the catchment area had visited the centre.
} 
Respondents were asked a set of knowledge questions, particularly focussing on HIV/AIDS as this is a focus of many of the programmes. There was little difference in knowledge between those that had been to the centres compared to those that had not. The only difference is that those that had not been to the centre were more knowledgeable about the fertile period of a girl compared to those that had not been to the centre, a difference that was statistically significant.

Boys who had visited the youth centre seemed to have initiated sex earlier than those that had never been to the centre. Figure 8 displays the cumulative probability of having sex by age, among those that had been to the centre versus those that had not. The median age at first sex for male youth centre visitors was 16.6 years, compared to 18.7 for non-visitors. While there are a number of interpretations of this finding, it is possible that this results from sexually experienced young people being more motivated to visit the centre for condoms and STI services. There was little difference in age at sexual debut among female visitors and nonvisitors (Figure 9). For female non-visitors, the median age at first sex was 18.8 years, compared to 18.4 for female visitors.

\section{Figure 8: Cumulative Probability of Boys Initiating Sex, by Youth Centre Exposure}

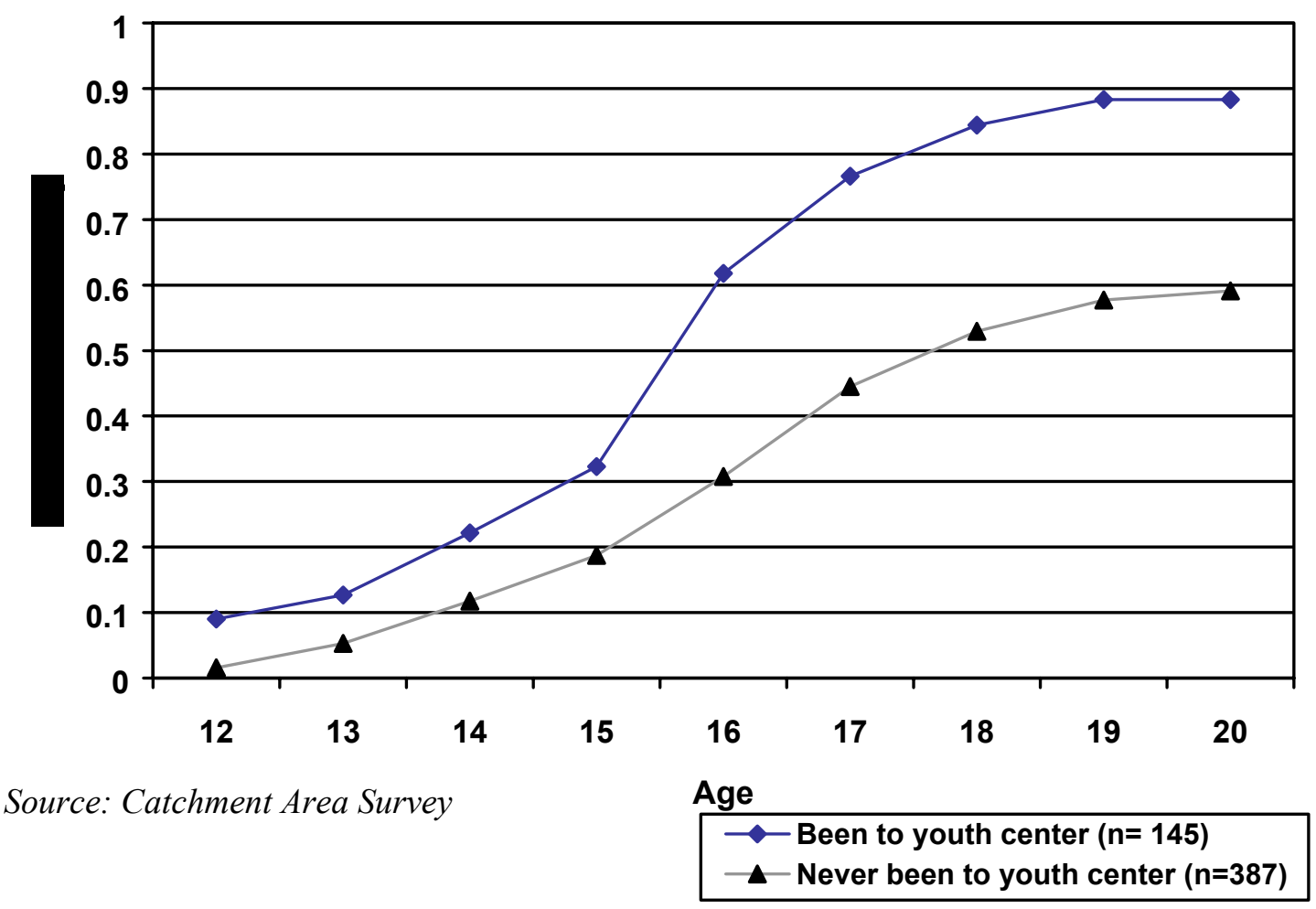

Regarding attitudes toward gender issues, young people who had been to the centres did not differ in their attitudes significantly compared to those who had not been to the centres. For only one opinion, whether women and men should have the same leadership opportunities in government, those who had never attended the centres had more liberal views compared to their counterparts who had attended the centres.

Among sexually experienced young people, there was little difference in condom use between those that had been to the centres versus those that had not. Among boys, 60 percent of those who had never been to the centre were currently using condoms compared to 59 percent of those that had been to the centre in the last three months. For girls, 30 percent of sexually experienced youth centre visitors were using condoms compared to 26 percent of 
non-visitors. However, girls who had visited the centre were significantly more likely to be using dual protection (42 percent of visitors versus 27 percent of non-visitors; $p<0.05$ ).

Differences in dual protection among boys were insignificant ( 5 percent of non-visitors and 4 percent of visitors).

Figure 9: Cumulative Probability of Girls Initiating Sex, by Youth Centre Exposure

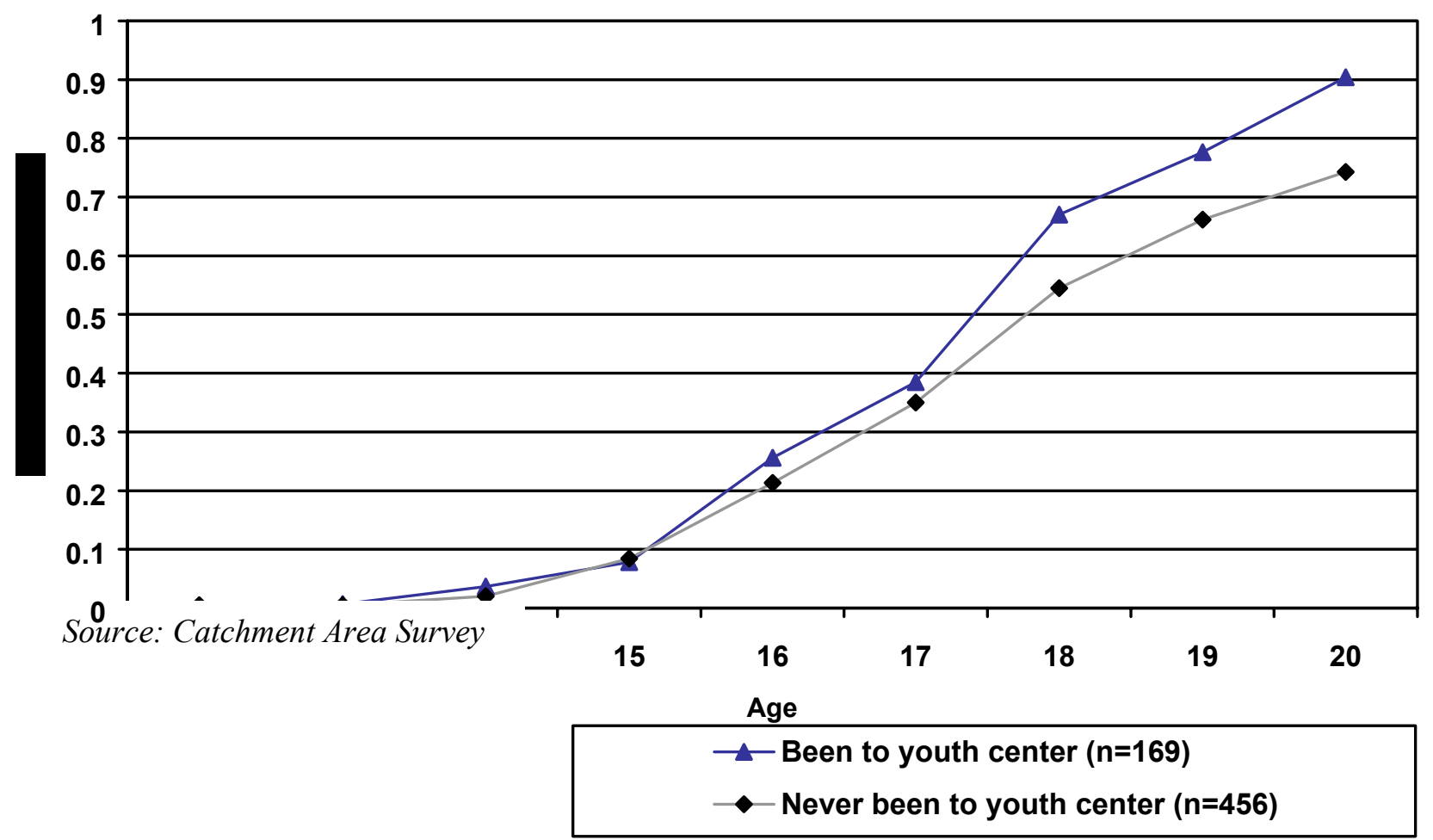




\section{CONCLUSIONS}

There is increased interest in youth centres as a programmatic model for reaching young people with information and services. This assessment sought to shed light on the quality, functioning and community perception of youth centres in South Africa being implemented by the loveLife programme, KZN DoH, and YARHP. The centres studied spanned a range of youth centre models, from the highly diversified loveLife multi-purpose centres, to the KZN DoH youth clinics, to the YARHP centres that experimented with different partnerships and types of facilities. The loveLife centres and the YARHP centres were in the early stages of development, while the KZN DoH centres had been in existence for many years.

Attendance at the youth centres varied with the activities that are offered there. Youth centres with a wide array of recreational activities tend to get more repeat visitors - usually younger males - than those with a narrow range of activities. A considerable number of youth centre visitors were outside the target age range, in particular, those coming for RH services. This suggests that there is a demand for these services by older adolescents and some of the more restrictive programmes, such as loveLife, might consider reviewing their target age range. While repeat and recreational visitors tended to be young males, clients for clinical services tend to be females. This could be due to the emphasis on family planning in the clinics and the increased demand of these services by girls compared to boys. Condoms, on the other hand, were generally not received from clinical personnel, but rather from dispensers or boxes in the clinics. Moreover, youth centres were not necessary the source of condoms for youth centre clients, with public sector hospitals and clinics being the most common source of condoms.

Peer educators are one of the main mechanisms for delivery of life skills in the centres. The assessment revealed that their activities are highly variable, with some peer educators reaching a large number of young people and others, very few. Further, the number of hours worked in a week, the venue of contents and the context of contacts (whether group or individual) is highly variable between programmes and within programmes. Few of the programmes reported standards or expectations for peer educators, such as a minimum number of hours worked or contacts made.

Programmes for young people are in their first generation, with little attention having been paid to evaluating their performance and coverage. This assessment underscored the importance of monitoring performance of programmes and understanding who is being reached with what interventions. Youth centres that focus on providing recreational facilities attract a large number of clients, often boys who are repeat visitors. Providing recreational facilities for young people may go a long way in satisfying programmes' developmental objectives. However, linkages between providing recreation and positive health outcomes are not clear-cut. Centres should not lose sight of their health objectives and should recognize that a significant proportion of young people are in need of quality RH information and services. Therefore, programmes should have ongoing monitoring of the numbers and profiles of young men and women reached with health inputs.

Coverage is another important aspect of programmes. This assessment revealed the youth centres reach about 30 percent of young people in the areas immediately surrounding them. It is likely that coverage is far lower in areas at a greater distance from the centre. With so much of Africa being rural, and with the majority of programmes working within extremely constrained budgets, it is unlikely that youth centres can adequately reach a significant proportion of young people in Africa. 
Finally, the assessment revealed that boys and girls utilize programmes for different reasons. Youth programmers should resist the temptation to homogenize boys and girls into a broad, genderless category "youth." Attention should be paid to the specific needs of boys and girls in designing programmes that satisfy their distinct RH needs.

\section{UTILISATION OF STUDY FINDINGS}

Following data collection and analysis for the study, two dissemination meetings were held in South Africa. The first meeting targeted key programme managers and donors of the organizations involved in this evaluation. The second meeting was a national dissemination reaching a wide array of organizations - both governmental and non-governmental - working in the area of adolescent development and sexual and reproductive health. The findings of the study were shared and recommendations discussed.

Based on the study results, each programme came up with recommendations to improve their own programmes. Specific recommendations, by programme, are outlined below:

\section{loveLife Programme}

- loveLife will develop a marketing strategy for their clinical services, with a view to increasing utilization. There has been some discussion that the term "clinic" may have negative associations for youth and, in particular, for young men. Repackaging their services and possibly renaming them is being considered.

- Findings suggest the need for a more comprehensive range of clinical services provided within an integrated environment. Although the centres provide a range of quality reproductive health services, problems are encountered by youth when they are referred. The need to minimise referral has led to plans for an expanded range of services, which will include voluntary counselling and testing (VCT) for HIV.

- With such a wide range of activities taking place in the loveLife centres, managers recognized the need to improve monitoring and documentation of all services.

This would improve monitoring changes in demand for different services, as well as planning the direction of services.

- The findings indicated that the age of service providers was not an issue for youth and that friendly staff rated far higher in importance as a criteria for youth friendliness than age of service provider. The programme no longer sees the need to select staff of a certain age to provide services.

- Discussion on opening hours has been raised with the possibilities of youth centres staying open later in the afternoon.

\section{DFID-UNFPA YARHP}

- The findings of this study will inform planning relating the development of YARHP centres and their expansion to other districts and municipalities. They will also inform dialogue between provincial/municipal health departments and the NGO sector to better promote effective youth and adolescent reproductive health services.

- The high incidence of sexual violence among young people suggests that this should become a key theme for health promotion and community mobilization initiatives in YARHP sites. 
- The findings relating to family planning use suggest a clear need to promote dual protection. This will become a priority in YARHP health education initiatives. Whilst the findings on condom use are encouraging, there remains a need to promote increased and consistent use, as well as greater awareness regarding access. Condom dispensers appear to be a favoured form of accessing condoms; hence the programme will explore creative ways of expanding this form of distribution.

- The findings relating to reproductive tract infections suggest that there is a need to place greater emphasis on partner referral. This will be explored as a theme within YARHP health promotion and counselling programmes.

- It is notable that when rating preferences for reproductive health services, young people did not rate 'youth only services' highly. This suggests that, in certain contexts, there may be a role for 'integrated' services in the expansion of youth and adolescent reproductive health initiatives. This theme will continue to be explored as part of the programme.

- Findings relating to awareness of and exposure to the Youth Centres indicate that there is considerable need for increased marketing of YARHP centres. It also seems that, for the YARHP centres, there is a particular need to target boys. Since many youth find out about the centres through friends, peer educators may be able to play a greater role in raising awareness about the centres.

- The client profile at the Youth Centres indicates that the mean age of attendance remains high. The YARHP sites will, therefore, place greater emphasis on targeting younger adolescents.

- Although the findings relating to the knowledge and attitudes of service providers is encouraging, there remains a need to address judgmental attitudes, particularly with respect to premarital sex and TOP. This will, therefore, be a priority theme in staff training and values clarification programmes.

- Similarly, there appears to be a further need to address the personal biases and judgmental attitudes of peer educators. These will be highlighted as theme for PPASA's training workshops.

- It is disappointing to find that young people who attend the youth centres do not have greater reproductive health knowledge than those who do not. This suggests a need to explore further opportunities for health education and counselling during visits to YARHP centres.

\section{Kwa-Zulu Natal Department Of Health}

- Data regarding timing of client visits suggested the need to restructure the services to accommodate youth attending after school hours. The mornings should be used for other activities including youth education, possibly encouraging visits from schools for talks and education. Parent sessions and community activities could also be scheduled for the mornings to promote and educate the community and ensure the services were seen as acceptable.

- Findings indicated low use and/or recording of dual protection and it appeared that clinics were not distributing condoms to youth who were using hormonal contraceptive methods. Although condoms were available at all the centres there is need for nurses to be at the front line of condom promotion. In particular, new 
clients should be counselled on the risks of using a hormonal method of contraception without combined use of a barrier method.

- The length of STI visits observed was often too short for full attention to the syndromic management protocol. Moreover, these visits should be seen as an opportunity to promote dual protection and raise the issues of risks of multiple sex partners. Providers may need training in tackling these sensitive issues with clients.

- Although most centres had IEC material available in waiting areas for youth to take away, it was suggested that providers should also play a central role in the distribution of relevant IEC material specific to the clients during the consultation. Almost all youth were literate and should be encouraged to read materials by staff who could guide them on what was appropriate for them.

- Centres catering for youth, in particular DOH clinics should adopt better networking with NGOs who could support them in a variety of ways. The Department of Education should also be seen as a major partner of youth centres. This would be an opportunity for both parties to send out the same messages, support joint projects and develop strategies to target youth.

Interestingly, each of the three programmes focussed on very different areas for improvement. loveLife programme managers focussed on strategies to improve clinical services, such as marketing the clinics in a way that is more appealing to youth and providing comprehensive services, including VCT. For YARHP centres, the study encouraged programme managers to be more circumspect and analytical about programmes, comparing the relative strengths and weakness of different models and contemplating alternative partnerships. KZN DoH clinics saw the need to increase condom promotion and dual method use, as well as provider competence during STI visits. All three programmes saw the need for improved monitoring and recording associated with the programme. The assessment highlighted that the performance of peer educators is highly variable and that the information they give to young people might, in some cases, be suspect. However, none of the programmes included re-examination of their peer education programmes as priority area, resulting from this assessment. 


\section{REFERENCES}

Department of Health, Medical Research Council, Macro International, Inc. 1998. South Africa Demographic and Health Survey, 1998: Preliminary Report.

Erulkar, Annabel S. and Barbara S. Mensch. 1997. Youth Centres in Kenya: Evaluation of the Family Planning Association of Kenya Programme. Nairobi: Population Council.

Glover, Evam Kofi, Annabel S. Erulkar, and Joana Nerquaye-Tetteh. 1998. Youth Centres in Ghana: Assessment of the Planned Parenthood Association of Ghana Programme. Nairobi: Population Council.

Jewkes, Rachel, Caisar Vundule, Fidelia Maforah, and Esme Jordaan. forthcoming. Relationship dynamics and adolescent pregnancy in South Africa. Social Science and Medicine.

Kerrigan, D., and Ellen Weiss. 2000. Peer Education and HIV/AIDS: Past Experience, Future Directions. Washington, DC: Population Council, May.

loveLife. 2000. "loveLife: talk about it." Programme summary. Parklands, South Africa: loveLife.

Making Connections: Achievement, Challenges and Lessons Learned from the UNFPA/DfID Youth and Adolescent Reproductive Health Programme: January, 1999 - January, 2001. 2001. Draft document.

Marques, Magaly. 1993. "Gente Joven/Young People: A Dialogue on Sexuality with Adolescents in Mexico," Quality/Calidad/Qualite, New York: The Population Council.

National Department of Health. 2000. Summary Report of the 2000 National HIV SeroPrevalence Survey of Women Attending Public Antenatal Clinics in South Africa. Pretoria: Health Systems Research and Epidemiology Directorate.

Phiri, Alford, and Annabel S. Erulkar. 1997. A Situation Analysis of the Zimbabwe National Family Planning Council's Youth Centres. Nairobi: Population Council.

Pisani, Elizabeth. 1999. "AIDS in the $21^{\text {st }}$ Century: Some Critical Considerations." SAFAIDS News, Vol. 7, No. 4, December.

Senderowitz, Judith. 1997. "Reproductive Health Outreach Programmes for Young Adults." FOCUS on Young Adults. Unpublished.

Townsend, John W. et. al. 1987. "Sex Education and Family Planning Services for Young Adults: Alternative Strategies in Mexico, ” Studies in Family Planning, Volume 18: 2, March/April.

WHO. 1997. "Action for Adolescent Health: Towards a Common Agenda: Recommendations from a Joint Study Group." Adolescent Health and Development, WHO, May.

WHO. 1999. "Programming for Adolescent Health and Development: Report of a WHO/UNFPA, UNICEF Study Group on Programming for Adolescent Health." WHO Technical Report Series, No. 886. 


\section{APPENDIX 1}

Data sources, methods, and sample sizes for study

\begin{tabular}{|c|c|c|c|c|}
\hline $\begin{array}{l}\text { Data } \\
\text { Source }\end{array}$ & Main Variables Measured & $\begin{array}{l}\text { Data } \\
\text { Collection } \\
\text { Method }\end{array}$ & Sampling & $\begin{array}{l}\text { Sample } \\
\text { Size }\end{array}$ \\
\hline & Mini Situation Analysis of Youth Centres & & & \\
\hline $\begin{array}{l}\text { Youth } \\
\text { Centre } \\
\text { Inventory }\end{array}$ & $\begin{array}{l}\text { Services offered; Equipment available; IEC } \\
\text { material available; Staff; Management } \\
\text { system (incl. MIS); Days and hours of } \\
\text { operation }\end{array}$ & \begin{tabular}{l|} 
Checklist \\
completed with \\
assistance of \\
centre manager \\
\end{tabular} & $\begin{array}{l}\text { All twelve youth } \\
\text { centres }\end{array}$ & 12 \\
\hline $\begin{array}{l}\text { Interviews } \\
\text { with youth } \\
\text { centre staff }\end{array}$ & $\begin{array}{l}\text { Demographic background of providers; } \\
\text { Training and qualifications; Attitudes toward } \\
\text { youth sexuality and } \mathrm{RH} \text {; Knowledge of RH; } \\
\text { Counselling skills }\end{array}$ & $\begin{array}{l}\text { Interviewer } \\
\text { administered } \\
\text { questionnaire }\end{array}$ & $\begin{array}{l}\text { All staff based } \\
\text { at the youth } \\
\text { centres }\end{array}$ & 44 \\
\hline $\begin{array}{l}\text { Interviews } \\
\text { with clients }\end{array}$ & $\begin{array}{l}\text { Demographic background; Source of } \\
\text { knowledge about the service; Time and } \\
\text { expense getting to the centre; Reason for } \\
\text { visiting the centre; Perceptions of staff } \\
\text { visited; Awareness and perceptions of } \\
\text { services offered; Awareness of peer } \\
\text { educators }\end{array}$ & $\begin{array}{l}\text { Interviewer } \\
\text { administered } \\
\text { questionnaire }\end{array}$ & $\begin{array}{l}\text { All clients. } \\
\text { For busy } \\
\text { centres, all RH } \\
\text { clients and a } \\
\text { sample of non- } \\
\text { RH clients. }\end{array}$ & 667 \\
\hline $\begin{array}{l}\text { Youth } \\
\text { Centre } \\
\text { Attendance } \\
\text { Register } \\
\end{array}$ & $\begin{array}{l}\text { Profile of visitors (sex, age, school status) } \\
\text { Reasons for visiting the centres; Time of } \\
\text { entry and exit; Frequency of visiting youth } \\
\text { centres }\end{array}$ & $\begin{array}{l}\text { Interviewer } \\
\text { administered } \\
\text { register }\end{array}$ & $\begin{array}{l}\text { All youth centre } \\
\text { visitors }\end{array}$ & 2444 \\
\hline \multirow[t]{2}{*}{$\begin{array}{l}\text { Nurse } \\
\text { Register }\end{array}$} & $\begin{array}{l}\text { Profile of clients getting RH services; Type } \\
\text { of services received; Time of entry and exit }\end{array}$ & $\begin{array}{l}\text { Register } \\
\text { completed by } \\
\text { nurse }\end{array}$ & $\begin{array}{l}\text { All clients seen } \\
\text { by all nurses } \\
\text { working at the } \\
\text { centres }\end{array}$ & $\begin{array}{l}742 \\
\text { (14 } \\
\text { nurses) }\end{array}$ \\
\hline & $\begin{array}{l}\text { Assessment of Peer Education } \\
\text { Programmes }\end{array}$ & & & \\
\hline $\begin{array}{l}\text { Interviews } \\
\text { with peer } \\
\text { educators }\end{array}$ & $\begin{array}{l}\text { Demographic background of peer } \\
\text { educators; Training and qualifications; } \\
\text { Attitudes toward youth sexuality and RH; } \\
\text { Counselling skills }\end{array}$ & $\begin{array}{l}\text { Interviewer } \\
\text { administered } \\
\text { questionnaire }\end{array}$ & $\begin{array}{l}\text { All peer } \\
\text { educators } \\
\text { affiliated with } \\
\text { the youth } \\
\text { centre }\end{array}$ & 108 \\
\hline \multirow[t]{2}{*}{$\begin{array}{l}\text { Peer } \\
\text { Educator } \\
\text { Register }\end{array}$} & $\begin{array}{l}\text { Profile of peer educator contacts (sex, age, } \\
\text { school status); Location of contact; Group } \\
\text { or individual session; Reason for contact; } \\
\text { Topics covered. }\end{array}$ & $\begin{array}{l}\text { Register } \\
\text { completed by } \\
\text { the peer } \\
\text { educator }\end{array}$ & $\begin{array}{l}\text { All peer } \\
\text { educator } \\
\text { contacts }\end{array}$ & $\begin{array}{l}1064 \\
(53 \\
\text { PEs) }\end{array}$ \\
\hline & Catchment Area Surveys & & & \\
\hline $\begin{array}{l}\text { Survey of } \\
\text { youth in the } \\
\text { centres' } \\
\text { catchment } \\
\text { areas }\end{array}$ & $\begin{array}{l}\text { Awareness of the youth centre and peer } \\
\text { educators; Perceptions of the youth centre } \\
\text { and peer educators Willingness to visit } \\
\text { youth centres/PEs and reason for use or } \\
\text { non-use of the service; Profile of youth in } \\
\text { the catchment area, including school and } \\
\text { work status, sexual behaviour, condom use } \\
\text { and health seeking behaviour }\end{array}$ & $\begin{array}{l}\text { Interviewer } \\
\text { administered } \\
\text { questionnaire }\end{array}$ & $\begin{array}{l}200 \\
\text { households } \\
\text { with at least } \\
\text { one youth aged } \\
12-24 \text { in the } \\
\text { catchment area } \\
\text { of } 7 \text { centres. }\end{array}$ & 1399 \\
\hline $\begin{array}{l}\text { Survey of } \\
\text { parents in } \\
\text { the centres' } \\
\text { catchment } \\
\text { areas }\end{array}$ & $\begin{array}{l}\text { Awareness of the youth centre and peer } \\
\text { educators; Perceptions of the youth centre } \\
\text { and peer educators; Willingness to allow } \\
\text { youth to visit centres/PEs and reason for } \\
\text { approval or non-approval. }\end{array}$ & $\begin{array}{l}\text { Interviewer } \\
\text { administered } \\
\text { questionnaire }\end{array}$ & $\begin{array}{l}\text { A } 25 \text { percent } \\
\text { sub-sample of } \\
\text { parents of } \\
\text { selected } \\
\text { adolescents. }\end{array}$ & 346 \\
\hline
\end{tabular}




\section{APPENDIX 2}

\section{Characteristics of youth centres included in the study ${ }^{12}$}

\begin{tabular}{|c|c|c|c|c|c|c|c|}
\hline $\begin{array}{l}\text { Name of } \\
\text { Centre }\end{array}$ & Province & $\begin{array}{l}\text { Type } \\
\text { of Site }\end{array}$ & Implementing Agency & Model & $\begin{array}{l}\text { Date } \\
\text { Opened }\end{array}$ & $\begin{array}{l}\text { Age Group } \\
\text { Targeted }\end{array}$ & Opening Hours \\
\hline $\begin{array}{l}\text { Acornhoek Y- } \\
\text { Centre }\end{array}$ & $\begin{array}{l}\text { Northern } \\
\text { Province }\end{array}$ & Urban & loveLife & $\begin{array}{l}\text { Stand alone } \\
\text { facility; } \\
\text { Multi-purpose } \\
\text { youth centre }\end{array}$ & $\begin{array}{l}\text { April, } \\
2000\end{array}$ & $12-17$ & $\begin{array}{l}\text { Monday- } \\
\text { Saturday } \\
\text { 11:00-18:00 (M- } \\
\text { F) } \\
\text { 12:00-18:00 (Sa) }\end{array}$ \\
\hline $\begin{array}{l}\text { Orange Farm } \\
\text { Y-Centre }\end{array}$ & Gauteng & $\begin{array}{l}\text { Peri- } \\
\text { urban }\end{array}$ & loveLife & $\begin{array}{l}\text { Stand alone } \\
\text { facility; } \\
\text { Multi-purpose } \\
\text { youth centre }\end{array}$ & $\begin{array}{l}\text { Sept. } \\
1999\end{array}$ & $10-20$ & $\begin{array}{l}\text { Monday- } \\
\text { Sunday; } \\
\text { 9:30-18:00 (M- } \\
\text { W) } \\
\text { 9:30-18:30 (Th- } \\
\text { F) } \\
\text { 9:00-16:00 (Sa) } \\
\text { 12:00-16:00 (Su) }\end{array}$ \\
\hline $\begin{array}{l}\text { Kutluanong Y- } \\
\text { Centre }\end{array}$ & Free State & $\begin{array}{l}\text { Peri- } \\
\text { urban }\end{array}$ & loveLife & $\begin{array}{l}\text { Stand alone } \\
\text { facility; } \\
\text { Multi-purpose } \\
\text { youth centre }\end{array}$ & $\begin{array}{l}\text { Nov. } \\
1999\end{array}$ & $12-17$ & $\begin{array}{l}\text { Monday- } \\
\text { Saturday; 8:00- } \\
\text { 18:00 (M-F), } \\
\text { 9:00-15:00 (S) }\end{array}$ \\
\hline $\begin{array}{l}\text { Sakhulutsha Y- } \\
\text { Centre }\end{array}$ & $\begin{array}{l}\text { Eastern } \\
\text { Cape }\end{array}$ & Urban & loveLife & $\begin{array}{l}\text { Stand alone } \\
\text { facility; } \\
\text { Multi-purpose } \\
\text { youth centre } \\
\end{array}$ & $\begin{array}{l}\text { July, } \\
1996\end{array}$ & $12-17$ & $\begin{array}{l}\text { Monday- } \\
\text { Saturday; 9:00- } \\
\text { 18:00 }\end{array}$ \\
\hline $\begin{array}{l}\text { Commercial } \\
\text { City Youth } \\
\text { Clinic }\end{array}$ & $\begin{array}{l}\text { KwaZulu- } \\
\text { Natal }\end{array}$ & Urban & Department of Health & $\begin{array}{l}\text { Stand alone } \\
\text { Youth Clinic }\end{array}$ & 1986 & $10-20$ & $\begin{array}{l}\text { Monday- } \\
\text { Saturday } \\
\text { 8:00-16:00 (M-F) } \\
\text { 8:00-12:00 (Sa) }\end{array}$ \\
\hline $\begin{array}{l}\text { Empangeni } \\
\text { Youth Clinic }\end{array}$ & $\begin{array}{l}\text { KwaZulu- } \\
\text { Natal }\end{array}$ & Urban & Department of Health & $\begin{array}{l}\text { Integrated } \\
\text { facility; } \\
\text { Youth Clinic }\end{array}$ & 1987 & $10-20$ & $\begin{array}{l}\text { Monday-Friday } \\
7.30-16: 00\end{array}$ \\
\hline $\begin{array}{l}\text { Mphambo } \\
\text { Youth Centre }\end{array}$ & $\begin{array}{l}\text { Northern } \\
\text { Province }\end{array}$ & Rural & $\begin{array}{l}\text { YARHP } \\
\text { Housed in DoH facility } \\
\text { PPASA contracted by } \\
\text { PDoH to implement }\end{array}$ & $\begin{array}{l}\text { Semi-integrated } \\
\text { facility; } \\
\text { Multi-purpose } \\
\text { youth centre }\end{array}$ & $\begin{array}{l}\text { Oct. } \\
1999\end{array}$ & $10-24$ & $\begin{array}{l}\text { Monday-Friday } \\
8: 30-17: 00\end{array}$ \\
\hline $\begin{array}{l}\text { Thlokomelo } \\
\text { Youth Centre } \\
\text { (Kimberley) }\end{array}$ & $\begin{array}{l}\text { Northern } \\
\text { Cape }\end{array}$ & Urban & $\begin{array}{l}\text { YARHP } \\
\text { Housed in a } \\
\text { Department of Welfare } \\
\text { facility; PPASA } \\
\text { contracted by PDoH to } \\
\text { implement }\end{array}$ & $\begin{array}{l}\text { Stand alone } \\
\text { facility; } \\
\text { Multi-purpose } \\
\text { youth centre }\end{array}$ & $\begin{array}{l}\text { Feb. } \\
2000\end{array}$ & $10-24$ & $\begin{array}{l}\text { Monday - } \\
\text { Saturday } \\
\text { 8:00-18:00 (M-F) } \\
\text { 12:00-18:00 (Sa) }\end{array}$ \\
\hline $\begin{array}{l}\text { Mmabatho } \\
\text { Youth Centre }\end{array}$ & $\begin{array}{l}\text { North West } \\
\text { Province }\end{array}$ & $\begin{array}{l}\text { Peri- } \\
\text { urban }\end{array}$ & $\begin{array}{l}\text { YARHP } \\
\text { Housed in Municipal } \\
\text { Cultural Centre; } \\
\text { PPASA contracted by } \\
\text { PDoH to implement }\end{array}$ & $\begin{array}{l}\text { Integrated } \\
\text { facility; } \\
\text { Multi-purpose } \\
\text { youth centre }\end{array}$ & $\begin{array}{l}\text { May, } \\
2000\end{array}$ & $10-24$ & $\begin{array}{l}\text { Monday-Friday } \\
8: 30-17: 30\end{array}$ \\
\hline $\begin{array}{l}\text { Motswedi } \\
\text { Youth Centre } \\
\text { (Vryberg) }\end{array}$ & $\begin{array}{l}\text { North West } \\
\text { Province }\end{array}$ & Urban & $\begin{array}{l}\text { YARHP } \\
\text { Housed in vacated } \\
\text { primary school ; PPASA } \\
\text { contracted by PDoH to } \\
\text { implement }\end{array}$ & $\begin{array}{l}\text { Stand alone } \\
\text { facility; } \\
\text { Multi-purpose } \\
\text { youth centre }\end{array}$ & $\begin{array}{l}\text { April, } \\
2000\end{array}$ & $10-24$ & $\begin{array}{l}\text { Monday-Friday } \\
8: 30-17: 00\end{array}$ \\
\hline $\begin{array}{l}\text { Moletsi Youth } \\
\text { Centre }\end{array}$ & $\begin{array}{l}\text { Northern } \\
\text { Province }\end{array}$ & Rural & $\begin{array}{l}\text { YARHP } \\
\text { Housed in a DoH } \\
\text { facility; PPASA } \\
\text { contracted by PDoH to } \\
\text { implement }\end{array}$ & $\begin{array}{l}\text { Integrated } \\
\text { facility; } \\
\text { Multi-purpose } \\
\text { youth centre }\end{array}$ & $\begin{array}{l}\text { Oct. } \\
1999\end{array}$ & $10-24$ & $\begin{array}{l}\text { Monday-Friday } \\
8: 30-17: 30\end{array}$ \\
\hline $\begin{array}{l}\text { Upington } \\
\text { Youth Centre }\end{array}$ & $\begin{array}{l}\text { Northern } \\
\text { Cape }\end{array}$ & Urban & $\begin{array}{l}\text { YARHP } \\
\text { Housed in a Municipal } \\
\text { health facility; PPASA } \\
\text { contracted by PDoH to } \\
\text { implement }\end{array}$ & $\begin{array}{l}\text { Integrated } \\
\text { facility; } \\
\text { Multi-purpose } \\
\text { youth centre }\end{array}$ & $\begin{array}{l}\text { March, } \\
2000\end{array}$ & $10-24$ & $\begin{array}{l}\text { Monday-Friday } \\
9: 30-18: 00\end{array}$ \\
\hline
\end{tabular}

\footnotetext{
${ }^{12}$ These were characteristics of the centres at the time of the study.
} 